\title{
The completion behaviour of registered apprentices in Canada: who continues, who quits, and who completes programs?
}

Christine Laporte ${ }^{1}$ and Richard E Mueller ${ }^{2^{*}}$

\author{
* Correspondence: \\ richard.mueller@uleth.ca \\ 2Department of Economics, \\ University of Lethbridge, \\ Lethbridge, AB T1K 3M4, Canada \\ Full list of author information is \\ available at the end of the article
}

\begin{abstract}
Background: The number of registered apprentices in Canada more than doubled between 1995 and 2007, yet successful completion of apprenticeship programs increased by only about one-third as much. Uncovering the factors related to low completion rates is a necessary first step to ensuring that today's skilled labour is replaced in the future.

Methods: This study utilizes a series of multinomial probit models and the 2007 National Apprenticeship Survey (NAS) to investigate the completion behaviour of individuals enrolled in apprenticeship programs. These behaviours include continuing, discontinuing (or quitting), and completing programs. The NAS contains detailed demographic information regarding respondents' backgrounds and the characteristics of apprenticeship programs.

Results: Program completion is positively related to a variety of demographic characteristics, including being married and having completed at least a high school education prior to beginning an apprenticeship. Males and females have similar completion probabilities. Completion is negatively related to time in the apprenticeship program (beyond the normal program length) and the number of employers during training. Type of technical training and having a journeyperson always present enhance the probability of completion. The regional unemployment rate has little effect on whether an individual completes an apprenticeship program or not. There are also large provincial and trade group differences.
\end{abstract}

Conclusions: Although this research has identified a number of factors correlated with apprenticeship completion, further research could address the benefits of completion such as wages and probability of employment. A more detailed examination of the variety of obstacles encountered by apprentices during training may also be useful in redesigning programs to enhance completion.

\section{Background}

Registration in apprenticeship programs has been increasing steadily over the last few years, but the growth in the number of completions has not kept pace. The Canadian Apprenticeship Forum (CAF) recently released a report which discusses nine barriers to accessing, persevering in, and successfully completing apprenticeship programs (CAF 2004, 2009). This report states that entry into programs is hampered by negative attitudes on the part of the public in general towards those occupations, lack of

\section{黛 Springer}


information, unwelcoming workplaces, and the costs of apprenticeships to employees, employers, and unions. Indeed, very few parents state a trade or vocational training as an aspiration that they have for their children. There is also a perceived lack of job stability, lower incomes, and the lower status of occupations requiring apprenticeship training relative to the other options open to Canadian youth (Sharpe and Gibson 2005). Côté and Allahar (2007:172) argue that “...to the extent that university can be mainly four to six years of fun, followed by years of higher salary, there is quite the incentive for people to forego other forms of post-secondary education like apprenticeships...".

This paper focuses on the pathways that registered apprentices take once they are enrolled in apprenticeship training. In many ways, this research is a logical continuation of the existing literature on access to, and persistence in, post-secondary education (PSE), which has largely focused on studying formal classroom training in colleges and universities. In general, these PSE studies involve addressing the determinants of: (1) entering the PSE education after the completion of high school; and (2) conditional on entering, persisting through until the program is completed. ${ }^{a}$ By definition, PSE encompasses all types of education following secondary (or high school) education, but apprenticeship training is rarely mentioned and certainly has not been much studied. This seems unfortunate, since the long-term apprenticeship completion rates remain low (Morissette 2008) even though the growth in the number of registered apprentices has outpaced the growth in the number of students attending universities.

This research gap in Canada may be due, at least in part, to the lack of adequate data necessary to study the subject as well as to the fact that relatively few (albeit a growing number of) Canadians pursue apprenticeships as their education choice. Compared to the data used to study the transitions from high school to university or college and from university or college to the labour market, there are few data sets that enable researchers to study transitions through apprenticeship programs.

Specifically, this work focuses on the demographic, labour market, and employer characteristics that are correlated with three outcomes -- or completion behaviours -of apprentices: long-term continuation, completion, and discontinuation. Are there differences between trades and in the provinces and territories, as provincial and territorial authorities regulate these trades? What are the characteristics of programs that result in higher completion probabilities? Do changes in the business cycle affect completion? Are apprentices who have previous education more likely to complete their apprenticeships than those who have not completed high school?

The majority of work to date has not been conducted for Canada, but rather for the United States and Australia and to a greater extent, Europe which is not surprising given the relative importance of apprenticeship training in countries such as Germany, Austria, and Switzerland. The work that has been done with Canadian data has been largely descriptive and has relied on narrowly focused surveys or on data such as the Registered Apprenticeship Information System (RAIS), an administrative database which is strong in the scope of its coverage, but weak in terms of pertinent covariates.

This paper offers a more comprehensive look at apprenticeship completion behaviour using the best available data for the task: the 2007 National Apprenticeship Survey (NAS). These data allow us to address the correlates of completion behaviour of Canadians who were registered in apprenticeships at some point in the 2002-2004 period. Using the 
postal codes in the NAS as well as the Postal Code Conversion File Plus (PCCF+) utility enables the linkage of individuals' records to the regional unemployment rate in the Labour Force Survey (LFS) and thus expand the analysis to address the importance of the unemployment rate to the persistence choice of individuals.

The results show that a variety of demographic and apprenticeship variables are related to completion, discontinuation, or long-term continuation in programs. These results are consistent with the findings of previous studies which were largely based on less analytical treatments of the subject. Contrary to previous work, which has generally linked the unemployment rate with apprenticeship registrations, only a weak correlation is found between the unemployment rate and apprenticeship completions. Thus, while macroeconomic conditions may have a significant impact on registration, the results suggest that these have only a small negative impact on long-term continuation, but no statistically significant effects on completion and discontinuation. It is also found that the educational backgrounds of apprentices are important, with those having at least a high school education more likely to complete. This suggests that a high school education is not a substitute for apprenticeship training; rather, it is a complement to apprenticeship training. Also relevant are a number of job-specific characteristics such as firm size, type of technical training, and the presence of a journeyperson during training. From this, it can be inferred that designing differently the programs that have low completion rates could possibly enhance completion probabilities.

The paper is organized into several sections. Section Literature review places the paper in the context of what is currently known about persistence in apprenticeship programs in Canada. Section Methods discusses the methodology employed; Section Data addresses the data used. Presentation and discussion of the results comprise Section Results and discussion. The final section, Section Conclusions, concludes the paper.

\section{Literature review}

\section{Trends in apprenticeship registrations and completions}

The number of Canadians registered in apprenticeship programs has grown considerably over the last dozen years. Table 1 shows the number of individuals registered in apprenticeship programs increasing by around 120\% between 1995 and 2007. Some of this increase is the result of growth in the non-traditional trades (i.e., the "other" category) due partially to the addition of a number of new trades (Skof 2006). Growth in the traditional trades (with the exception of industrial and related mechanical) has also at least doubled; some of this increase is the result of greater female involvement in the major trades.

Over this same 12-year period, enrollments in undergraduate programs in Canada grew by only $36 \%$ from the $1995-1996$ to the $2007-2008$ academic years. ${ }^{\text {b }}$ In fact, this recent growth in apprentices has put their numbers at almost $84 \%$ of the number of full-time college students at about the same time. ${ }^{c}$

Despite the large increase in apprenticeship registrations, the proportion of registered apprentices completing their programs has actually fallen; thus, the increase in completions has not kept pace with the growth in registrations. In Table 2, the overall completion rate-calculated as the number of completers divided by the number of individuals who have registered-decreases from about $10.5 \%$ in 1995 to less than $7.0 \%$ in $2007 .^{\text {d }}$ Building construction trades and other trades have the lowest rates, while the food and service industry and industrial and mechanical technologies have the highest in every 
Table 1 Number of registered apprentices, by sex and major trade group, Canada, 1995 and 2007

$\begin{array}{rrrrrrr}\begin{array}{r}\text { Building } \\ \text { construction }\end{array} & \begin{array}{r}\text { Electrical, } \\ \text { electronics } \\ \text { and related }\end{array} & \begin{array}{r}\text { Food } \\ \text { and } \\ \text { service }\end{array} & \begin{array}{r}\text { Industrial } \\ \text { and related } \\ \text { mechanical }\end{array} & \begin{array}{r}\text { Metal } \\ \text { fabricating }\end{array} & \begin{array}{r}\text { Motor } \\ \text { vehicle } \\ \text { and heavy } \\ \text { equipment }\end{array} & \begin{array}{r}\text { Other } \\ \text { Total, } \\ \text { major } \\ \text { trade } \\ \text { groups }\end{array}\end{array}$

\begin{tabular}{lrrrrrrrr} 
& \multicolumn{10}{c}{ equipment } & groups \\
\hline $\mathbf{1 9 9 5}$ & & & & & & & & \\
Both sexes & $\mathbf{3 4 , 7 8 5}$ & $\mathbf{2 9 , 2 1 5}$ & $\mathbf{1 5 , 1 0 0}$ & $\mathbf{1 3 , 5 5 0}$ & $\mathbf{3 3 , 4 6 5}$ & $\mathbf{3 4 , 3 9 0}$ & $\mathbf{2 , 8 6 0}$ & $\mathbf{1 6 3 , 3 7 0}$ \\
Male & 33,910 & 28,685 & 6,875 & 13,340 & 33,070 & 33,775 & 2,290 & $\mathbf{1 5 1 , 9 4 5}$ \\
Female & 875 & 525 & 8,225 & 215 & 400 & 620 & 570 & $\mathbf{1 1 , 4 2 5}$ \\
Percent & 3 & 2 & 54 & 2 & 1 & 2 & 20 & 7 \\
female & & & & & & & & 7 \\
\hline
\end{tabular}

\begin{tabular}{|c|c|c|c|c|c|c|c|c|}
\hline \multicolumn{9}{|l|}{2007} \\
\hline Both sexes & 80,205 & 59,945 & 32,100 & 24,125 & 76,685 & 69,875 & 15,615 & 358,555 \\
\hline Male & 77,260 & 58,175 & 11,365 & 23,655 & 74,575 & 67,960 & 7,495 & 320,485 \\
\hline Female & 2,950 & 1,770 & 20,735 & 470 & 2,110 & 1,915 & 8,115 & 38,070 \\
\hline $\begin{array}{l}\text { Percent } \\
\text { female }\end{array}$ & 4 & 3 & 65 & 2 & 3 & 3 & 52 & 11 \\
\hline \multicolumn{9}{|c|}{ Growth, 1995-2007 } \\
\hline Both sexes & 130.6 & 105.2 & 112.6 & 78.0 & 129.1 & 103.2 & 446.0 & 119.5 \\
\hline Male & 127.8 & 102.8 & 65.3 & 77.3 & 125.5 & 101.2 & 227.3 & 110.9 \\
\hline Female & 237.1 & 237.1 & 152.1 & 118.6 & 427.5 & 208.9 & $1,323.7$ & 233.2 \\
\hline
\end{tabular}

Source: Authors' calculations from Statistics Canada and Council of Ministers of Education Canada. 2009. Education Indicators in Canada: Report of the Pan-Canadian Education Indicators Program. Catalogue no. 81-582-XIE, Table D.1.2.

year. For university undergraduates, this ratio has decreased marginally, from $31.2 \%$ to $29.9 \%$ over the same period. ${ }^{\mathrm{e}}$

Figure 1 shows a graphical representation of the evolution of apprenticeship registrations and completions relative to the comparable evolution for university undergraduates over the 1995-to-2007 period.

Compared to other forms of PSE, such as college and university, the requirements for apprenticeship programs tend to be less homogenous and the path to completing these programs is not as straightforward and structured. There are 13 jurisdictions in Canada with respect to education (ten provinces and three territories), each registering dozens of apprenticeship programs. Some of these programs are closely related, others not. Programs have different requirements for theoretical or classroom and on-the-job or hands-on training. The most recent version of the Ellis Chart-which compares apprenticeship programs across all 13 Canadian jurisdictions-lists close to 400 apprenticeships, some of which are related and not all of which are available in all jurisdictions (e.g., florists only in British Columbia and poissonnier/poissonnière [fish cooking and fish selling] only in Québec). ${ }^{\mathrm{f}}$ The minimum number of hours and years needed to complete programs also can differ as can other program requirements (e.g., some journeyperson exams can be challenged without an apprenticeship, others not).

Factors behind low apprenticeship completion rates

Demographic characteristics Apprentices tend to be older than college and university students; hence, apprenticeships are not considered as a school-to-work transition in the same way as other PSE options are (Gunderson 2009). Because they are older, 
Table 2 Percentage of completions to registered apprentices, by sex and major trade group, Canada, 1995, 2000, and 2003 to 2007

\begin{tabular}{rrrrrrr}
$\begin{array}{r}\text { Building } \\
\text { construction }\end{array}$ & $\begin{array}{r}\text { Electrical, } \\
\text { electronics } \\
\text { and related }\end{array}$ & $\begin{array}{r}\text { Food } \\
\text { and } \\
\text { service }\end{array}$ & $\begin{array}{r}\text { Industrial } \\
\text { and related } \\
\text { mechanical }\end{array}$ & $\begin{array}{r}\text { Metal } \\
\text { fabricating }\end{array}$ & $\begin{array}{r}\text { Motor } \\
\text { vehicle } \\
\text { and heavy } \\
\text { equipment }\end{array}$ & $\begin{array}{r}\text { Other } \\
\text { major } \\
\text { trade } \\
\text { groups }\end{array}$ \\
\hline
\end{tabular}

\begin{tabular}{|c|c|c|c|c|c|c|c|c|}
\hline \multicolumn{9}{|l|}{1995} \\
\hline Both sexes & 7.2 & 10.4 & 15.9 & 12.0 & 10.4 & 10.9 & 9.1 & 10.5 \\
\hline Male & 7.3 & 10.5 & 11.2 & 12.0 & 10.4 & 11.0 & 9.4 & 10.0 \\
\hline Female & 3.4 & 8.6 & 19.8 & 16.3 & 7.5 & 4.8 & 7.9 & 16.1 \\
\hline \multicolumn{9}{|l|}{2000} \\
\hline Both sexes & 5.2 & 8.3 & 12.9 & 10.1 & 9.6 & 11.6 & 6.8 & 9.2 \\
\hline Male & 5.2 & 8.3 & 9.3 & 10.2 & 9.6 & 11.7 & 7.4 & 8.9 \\
\hline Female & 2.6 & 7.5 & 15.2 & 5.9 & 5.0 & 7.9 & 5.9 & 12.3 \\
\hline \multicolumn{9}{|l|}{2003} \\
\hline Both sexes & 4.7 & 6.7 & 8.4 & 9.8 & 8.4 & 8.6 & 5.1 & 7.4 \\
\hline Male & 4.8 & 6.7 & 5.7 & 9.9 & 8.5 & 8.6 & 4.3 & 7.3 \\
\hline Female & 3.4 & 4.3 & 10.0 & 5.7 & 4.4 & 6.5 & 6.0 & 8.3 \\
\hline \multicolumn{9}{|l|}{2004} \\
\hline Both sexes & 4.3 & 7.7 & 8.6 & 10.3 & 8.8 & 7.8 & 4.4 & 7.4 \\
\hline Male & 4.3 & 7.8 & 5.3 & 10.4 & 8.8 & 7.9 & 4.1 & 7.2 \\
\hline Female & 3.0 & 6.8 & 10.5 & 5.6 & 6.8 & 5.2 & 4.6 & 8.5 \\
\hline \multicolumn{9}{|l|}{2005} \\
\hline Both sexes & 4.3 & 7.6 & 8.4 & 9.3 & 7.9 & 7.7 & 4.0 & 7.0 \\
\hline Male & 4.4 & 7.7 & 5.7 & 9.4 & 7.9 & 7.8 & 3.9 & 6.9 \\
\hline Female & 2.2 & 5.0 & 9.9 & 7.8 & 6.0 & 5.1 & 4.2 & 7.7 \\
\hline \multicolumn{9}{|l|}{2006} \\
\hline Both sexes & 4.2 & 7.6 & 7.1 & 8.6 & 6.7 & 6.8 & 3.8 & 6.4 \\
\hline Male & 4.3 & 7.6 & 4.3 & 8.6 & 6.7 & 6.9 & 3.1 & 6.3 \\
\hline Female & 2.2 & 6.0 & 8.6 & 4.5 & 5.1 & 4.3 & 4.4 & 6.8 \\
\hline \multicolumn{9}{|l|}{2007} \\
\hline Both sexes & 4.9 & 7.6 & 8.4 & 8.8 & 7.0 & 7.6 & 3.0 & 6.8 \\
\hline Male & 5.0 & 7.8 & 5.0 & 8.9 & 7.1 & 7.7 & 2.4 & 6.8 \\
\hline Female & 2.4 & 4.0 & 10.3 & 4.3 & 4.0 & 5.0 & 3.6 & 7.3 \\
\hline
\end{tabular}

Source: Authors' calculations from Statistics Canada and Council of Ministers of Education Canada. 2009. Education Indicators in Canada: Report of the Pan-Canadian Education Indicators Program. Catalogue no. 81-582-XIE, Tables D.1.2 and D.2.2.

individuals who enter into apprenticeships tend to have significant labour market experience before commencement of an apprenticeship program. As a result, there may be little incentive to completing apprenticeship programs since those who do so may not enjoy significant post-apprenticeship employment or earnings advantages. This differs from other forms of PSE, such as university, where the sheepskin effects can be substantial. Indeed, Ferrer and Riddell (2002) argue that the importance of credentials in terms of earnings increases with education level. Stated differently, the penalty for non-completion (in terms of forgone earnings) may be higher for other forms of PSE than it is for apprenticeship training.

The limited evidence, however, paints a different picture of the labour-market disadvantages to non-completion. Akyeampong (1991) shows that, 12 months following the termination of a program (graduation or dropping out), dropouts make $77 \%$ of the hourly 


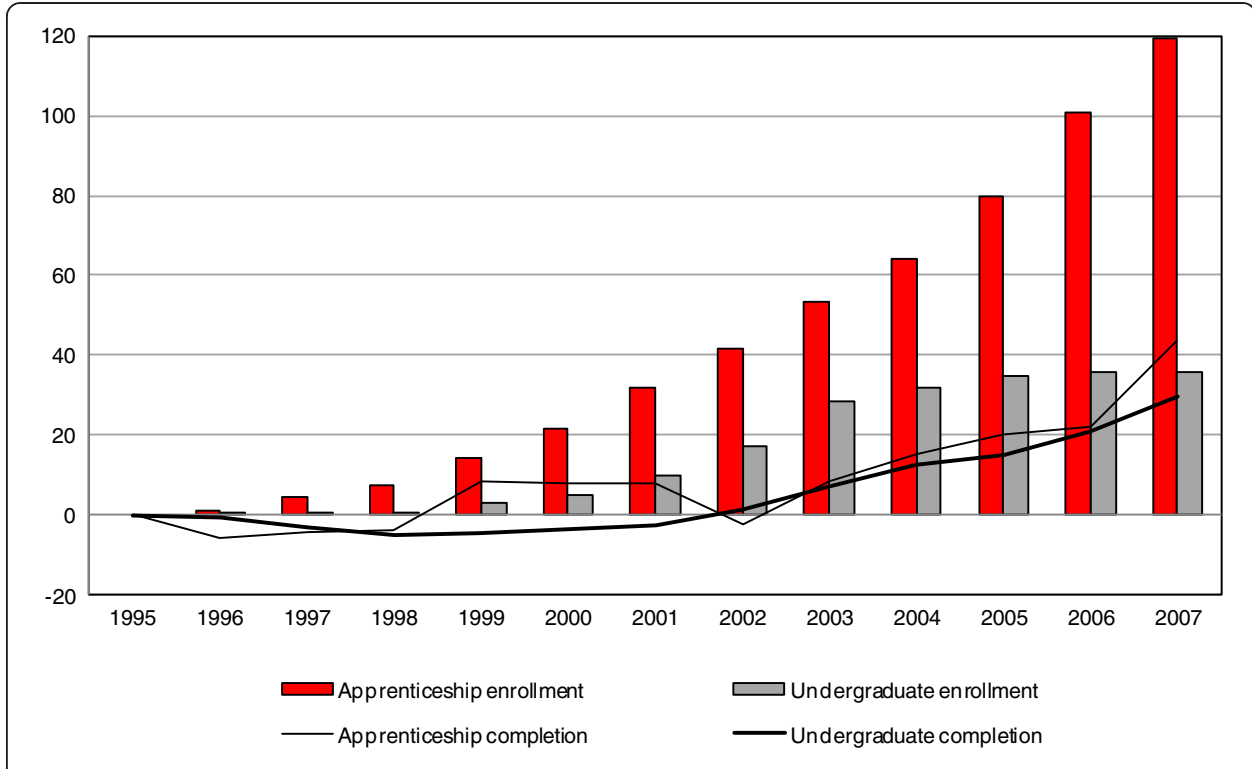

Figure 1 Percentage changes in enrollment and completion of apprentices and undergraduates.

wage of journeymen whereas graduates earn $81 \%$. However, dropouts are less likely to be employed in the trade in which they apprenticed (52\% vs. 96\%) and have worked fewer months in the last 12-month period (8.5 vs. 11.5). Other evidence (Ménard et al. 2008) is also consistent with this: apprentices who completed their programs had an $88 \%$ employment rate (compared to an employment rate of $82 \%$ for those who discontinued their programs) and they were more likely to hold permanent jobs (80\% vs. $76 \%$ ). Furthermore, median wages for completers were $\$ 27$ per hour in 2007, compared to $\$ 20$ per hour for discontinuers. Together, these results suggest that the penalty to withdrawing from an apprenticeship program may be substantial when both wage and non-wage factors are considered. ${ }^{\mathrm{g}}$

Other demographic differences may also be related to completion behaviour. US evidence presented by Bilginsoy (2003) shows that women and racial minorities were more likely to cancel apprenticeship programs after enrolling-and were less likely to complete them - than their white male counterparts.

Parental education is one of the largest predictors of attendance at colleges and universities in Canada (see Finnie et al. 2008, 2010). Lehmann (2004) also shows that parental background is important in determining apprenticeship status: fathers with lower levels of education in both Canada and Germany are more likely to have their children in the apprenticeship stream-rather than in the academic stream.

The business cycle and apprenticeship training The question that has been most explored in the literature is the relationship of business cycle to apprenticeship enrollment/completion. The cyclicality of apprenticeship registrations must be viewed in a demand-supply framework. There are several reasons why the business cycle may be responsible for changing the number of apprentices.

On the demand side, employers may not have the physical capacity or the financial resources necessary to hire apprentices, especially when the required ratio of journeypersons to apprenticeships is fixed. They may also worry that their investment 
in training could be lost if trained apprentices were recruited by competing firms. Alternatively, employers may find that taking on more apprentices is an economical way to train workers-both in general and to the firm's specifications-thus ensuring a supply of journeypersons when the economy improves. Apprentices may also provide flexibility in staffing for employers if they are able to work when needed and to pursue their classroom training at other times.

On the supply side, lower demand for their services may cause individuals to rethink that completing their program is the best option and to move on to other types of education (e.g., college or university) or directly to the labour market in another field. Conversely, high unemployment rates may drive individuals into apprenticeships, just as the demand for colleges and universities increases during an economic slowdown. It is possible that, during economic expansions, apprentices are able to find good jobs without completing their programs, thus increasing the probability of non-completion-either by discontinuing or through long-term continuation.

In sum, existing labour market theory does not provide a definitive direction of change in response to the macroeconomic conditions. Compared to colleges and universities, the confounding factor in apprenticeship training is a dynamic interaction of demand and supply which determines the number of apprenticeships available. In the case of universities and colleges, the number of students may increase, whereas the availability of spots may adjust only slowly and passively in response to demand changes.

The evidence that does exist on the effects of the business cycle is mixed. Although enrollments in more formal post-secondary education (i.e., colleges and universities) are countercyclical, the opposite is true for registrations in Canadian apprenticeships, where registrations tend to be procyclical (Sharpe and Gibson 2005; Skof 2006).

Although the number of new registrations may be sensitive to the oscillations of the business cycle, it is unclear what the pattern of completion behaviour of those already registered is, and there is little evidence anywhere. An exception in the Australian state of Queensland shows that apprenticeship quit rates increase when regional employment growth is high (Mangan and Trendle 2008a). Mangan and Trendle argue that economic growth provides more opportunities for apprentices, increasing the probability that they will terminate their training. However, they limit their sample to youth apprentices (aged 15 to 24); consequently, these results may not generalize to the Canadian case, where apprentices tend to be much older.

In contrast, Bilginsoy (2003) provides evidence for the US which suggests that the number of apprentices is higher during a downturn. More specifically, both cancellations and completions are procyclical as an expanding economy means a higher opportunity cost of remaining in an apprenticeship program. Furthermore, recruitment of employees by competing firms is likely to be a factor during economic expansions. However, in some countries (such as Switzerland), apprentice contracts are binding and cannot be terminated unilaterally, making this outcome less likely (Mühlemann et al. 2009).

In his review of the apprenticeship and on-the-job-training literature, Brunello (2009) notes that most studies indicate that the apprenticeship-employee ratio is mildly procyclical, whereas training (not including apprentices) tends to be counter-cyclical. He explains this apparent contradiction by noting that firms may have incentives to train incumbent workers during a downturn at the same time that they reduce the investment in training new employees (i.e., apprentices). 
For Canada, Sharpe and Gibson (2005) note that anecdotal evidence suggests that, when jobs are scarce, apprentices are laid off and cannot obtain the number of hours needed to complete their programs. During economic booms, they also may not be able to take time off to complete classroom requirements. Both of these situations can affect completion probabilities. For example, the authors note that, while the number of apprenticeship registrations grew by 90.8\% between 1991 and 2002, an expansionary period, the number of completions actually declined by $5.3 \%$.

Other factors related to low apprenticeship completion Bilginsoy (2003) shows that membership in a union is positively related to completion rates. In particular, apprenticeship programs in the US that are jointly sponsored by trade unions and employers have higher completion rates compared to those operated unilaterally by employers. Sweet and Lin (1999, cited in Raykov and Livintstone, 2005) also find a positive relationship between unionization and apprenticeship completion in Canada.

Having knowledge of the trades at an early age may also be a factor in successful apprenticeship completion. All provinces offer some sort of youth apprenticeship program (YAP) where young people can work in a trade while completing their high school diplomas. High school students may not be registered in a YAP but may nevertheless be exposed to various trades by taking trade and vocational courses, by taking part in co-op or high school work experience programs, or (in Québec only) by completing a diplôme d'études professionnelles (DEP). These programs allow high school students to "get their feet wet" in trades-related programs and may provide a transition to the labour market for a number of Canadian youth, although participation in these programs is rather low (CAF 2010).

\section{Methods}

The well-established methodology in the literature addressing persistence in programs is the multinomial logit model (e.g., Finnie and Qiu (2008) on the persistence of young Canadians in colleges and universities). However, multinomial logit models impose the inconvenient "independence of irrelevant alternatives" (IIA) restriction. IIA implies that adding another alternative does not affect the relative odds between all alternatives. This implication is implausible for applications with similar alternatives (see McFadden (1974) for the famous "red-bus-blue-bus" example of modes of transportation). Following Hausman and Wise (1978), a multinomial probit model is employed in order to avoid imposing this IIA assumption. ${ }^{\text {h }}$

After entering into an apprenticeship program, an individual has three choices: staying in the program; leaving the program prior to completion; or completing the program.

The general model for the latent variable $y^{*}{ }_{i j}$ can be written as

$$
\mathrm{y}_{\mathrm{ij}}^{*}=\mathrm{x}_{i}^{\prime} \beta_{\mathrm{j}}+\epsilon_{\mathrm{ij}} .
$$

In the multinomial probit model, it is assumed that the $\epsilon_{\mathrm{ij}}$ 's follow a multivariate normal distribution with covariance matrix $\Sigma$, where $\Sigma$ is not restricted to be a diagonal matrix (i.e., it allows the $\epsilon^{\prime}$ 's to be correlated with each other). 
Category $\mathrm{j}$ is chosen by individual $i$ if $y^{*}{ }_{i j}$ is highest for $j$, i.e.:

$$
y_{i}=\| \begin{array}{ll}
j & \text { if } y_{i j}^{*}=\max \left(y_{i 1}^{*}, y_{i 2}^{*}, \ldots, y_{i M}^{*}\right) \\
0 & \text { otherwise. }
\end{array}
$$

The probability of choosing category $j$ can be written as:

$$
P\left(y_{i}=j \mid x_{i}\right)=\left(y_{i j}^{*}>y_{i 1}^{*}, \ldots, y_{i j}^{*}>y_{i(j-1)}^{*}, y_{i j}^{*}>y_{i(j+1)}^{*}, \ldots, y_{i j}^{*}>y_{i M}^{*}\right)
$$

where $\mathrm{j}=1, \ldots, \mathrm{M}$ and $\mathrm{i}=1, \ldots, \mathrm{N}$. The variable $y_{i}$ is the persistence measure of interest at the time of the survey in 2007. The $x_{i}^{\prime}$ s are vectors of covariates that influence $y_{i}$, and the $\beta_{j}$ 's are the coefficients associated with each set of $x$. In this case, $M=3$ and $j=1$ indicates a long-term continuer, $\mathrm{j}=2$ indicates a completer, and $\mathrm{j}=3$ indicates a discontinuer.

The $x_{i}$ variables contain demographic information on the individual as well as the most conventional background variables that have been shown to have an impact on persistence in apprenticeship. They include variables such as age, marital status, highest level of education prior to beginning the apprenticeship program, etc. Additional $x_{i}$ variables are added in a blockwise fashion and include the wider range of variables available in the NAS. They are comprised of various ability measures, such as the individual's high school grades, registration in a YAP, length of time registered as an apprentice, trade group and local area economic conditions (from the LFS). Since apprenticeship programs are regulated by provincial and territorial authorities, provincial dummy variables are included in order to capture any systemic differences between provinces. ${ }^{j}$ The NAS does contain information on the involvement of parents in the trade in which the apprentice is registered. These types of variables are used as a proxy for parental education in the models. Finally, various job-related characteristics such as firm size are added to the estimated model.

\section{Data}

The Statistics Canada 2007 National Apprenticeship Survey (NAS) gathers information on the training and employment of apprentices across Canada. The survey's sample frame consists of all registered apprentices on the lists of apprentices provided by the provincial and territorial jurisdictions (except for Nunavut) for the 2002, 2003, and 2004 reference years. A total of 30,572 respondents were interviewed. The survey was conducted between January and May $2007 .^{\mathrm{k}}$

These data are useful for studying the persistence behaviour of apprentices, since they contain detailed data on three groups: ${ }^{1}$

- long-term continuers (LTCs) - those who have been registered for more than 1.5 times the normal program length;

- completers-those who have completed apprenticeship program requirements; and

- discontinuers-those who left the program without completing.

Each respondent to the survey is classified into one of these three groups for the 2002-2004 frame and again in 2007 at the time of the survey. Of course, there is movement between these three groups between 2002-2004 and 2007. For the purpose of this 
analysis, the 2007 categories are used as the dependent variable, although analysis using the 2002-2004 categories yielded similar results.

Each group was asked a set of questions on topics such as pre-apprenticeship education, training and work experiences, work as apprentice, reasons why discontinuers do not complete their programs, difficulties encountered during apprenticeship and general socio-demographic characteristics.

The NAS also contains information on postal codes at time of registration and at time of the survey. Using the Statistics Canada Postal Code Conversion File Plus $(\mathrm{PCCF}+)$ and Labour Force Survey, individuals can be matched with their local unemployment rates (using economic region as the reference).

An important limitation of these data is the lack of comprehensive coverage in Québec. There is a major difference in the scope of the survey between Québec and the other provinces and territories. According to the Microdata User Guide for the NAS (Statistics Canada 2008), comparisons of estimates between the province of Québec and other provinces should be avoided unless the comparison is made with similar trades. For this reason, Québec is dropped from the main analysis that follows.

Other restrictions on the sample used in the analysis are kept to a minimum in order to make the analysis as representative as possible. Only the following groups have been deleted from the sample: those who indicated inconsistent status between 2002-2004 and 2007 (i.e. those who had completed their program in 2002-04 and indicated they were "discontinuers" or "long-term continuers" in 2007), those who had different trades between 2002-2004 and 2007, those who did not work at all as apprentices between 2000 and 2007 (inclusively), those who started their apprenticeship program before age $16^{\mathrm{m}}$, and those who gave unclear responses, or who had missing responses, or responded "don't know" or "do not apply" responses for the key variables used in the analysis. These amount to a limited number of deletions. Survey weights provided by Statistics Canada are used in the analysis.

The final sample consists of 21,939 observations-representing about three times that many Canadians-involved in apprenticeship programs during the 2002-2004 survey frame.

\section{Results and discussion}

\section{Summary statistics}

Table 3 presents the summary statistics for each of the three groups: long-term continuers (LTCs), completers, and discontinuers. These results are generally consistent with the literature in this area. The weighted proportion of LTCs, completers, and discontinuers are $0.23,0.64$, and 0.13 , respectively. Males dominate in all three categories. The fact that the mean age for all three categories is well-over 30 years of age also shows that apprentices tend to be much older than those who attend university or college.

Completers are more likely to have at least a high school education (and higher levels of education in general) than LTCs or discontinuers. Completers are also more apt than the other two groups to have three to five years in the program. As expected, LTCs tend to have spent more time in their programs, and discontinuers less. This latter statistic suggests that most discontinuers leave their programs relatively early. ${ }^{\mathrm{n}}$

A cursory look at the proportion in each of the three groups at the provincial or territorial level and by detailed trade group shows that completion rates between trades can differ substantially. 
Table 3 Summary statistics for long-term continuers, completers and discontinuers, 2007

\begin{tabular}{|c|c|c|c|c|c|c|}
\hline \multirow[b]{2}{*}{ Variable } & \multicolumn{2}{|c|}{ LTCs } & \multicolumn{2}{|c|}{ Completers } & \multicolumn{2}{|c|}{ Discontinuers } \\
\hline & Mean & Std. Dev. & Mean & Std. Dev. & Mean & Std. Dev. \\
\hline Male & 0.894 & (0.308) & 0.867 & $(0.339)$ & 0.879 & $(0.327)$ \\
\hline Female & 0.106 & $(0.308)$ & 0.133 & $(0.339)$ & 0.121 & $(0.327)$ \\
\hline Age in 2007 & 33.490 & (8.074) & 33.043 & $(7.563)$ & 32.363 & $(8.648)$ \\
\hline \multicolumn{7}{|l|}{ Marital status at end } \\
\hline Married & 0.569 & $(0.495)$ & 0.530 & $(0.499)$ & 0.396 & $(0.489)$ \\
\hline Divorced & 0.062 & $(0.242)$ & 0.043 & $(0.202)$ & 0.054 & $(0.226)$ \\
\hline Single & 0.369 & $(0.483)$ & 0.428 & $(0.495)$ & 0.550 & $(0.498)$ \\
\hline $\mathrm{Nb}$ of children $<18$ & 0.936 & $(1.143)$ & 0.664 & $(1.018)$ & 0.593 & $(1.027)$ \\
\hline Aboriginal & 0.066 & $(0.248)$ & 0.045 & $(0.206)$ & 0.071 & $(0.257)$ \\
\hline Visible minority & 0.088 & $(0.284)$ & 0.063 & $(0.243)$ & 0.061 & $(0.239)$ \\
\hline White & 0.846 & $(0.361)$ & 0.893 & $(0.310)$ & 0.868 & $(0.339)$ \\
\hline Immigrant & 0.101 & $(0.302)$ & 0.086 & $(0.280)$ & 0.080 & $(0.271)$ \\
\hline Immigrant father & 0.255 & $(0.436)$ & 0.219 & $(0.414)$ & 0.199 & $(0.399)$ \\
\hline Immigrant mother & 0.231 & $(0.422)$ & 0.204 & $(0.403)$ & 0.187 & $(0.390)$ \\
\hline Disability at beginning & 0.046 & $(0.209)$ & 0.026 & $(0.158)$ & 0.038 & $(0.191)$ \\
\hline \multicolumn{7}{|l|}{ Education } \\
\hline Less than high school & 0.175 & $(0.380)$ & 0.107 & $(0.309)$ & 0.152 & $(0.360)$ \\
\hline High school & 0.517 & $(0.500)$ & 0.529 & $(0.499)$ & 0.512 & $(0.500)$ \\
\hline Trade-vocational & 0.059 & $(0.236)$ & 0.073 & $(0.261)$ & 0.075 & $(0.264)$ \\
\hline College & 0.199 & $(0.399)$ & 0.221 & $(0.415)$ & 0.196 & $(0.397)$ \\
\hline University & 0.049 & $(0.216)$ & 0.069 & $(0.253)$ & 0.064 & $(0.244)$ \\
\hline Unknown & 0.001 & $(0.033)$ & 0.001 & $(0.025)$ & 0.000 & $(0.012)$ \\
\hline \multicolumn{7}{|c|}{ Number of years in program } \\
\hline Less than 1 year & 0.038 & $(0.191)$ & 0.031 & $(0.174)$ & 0.272 & $(0.445)$ \\
\hline 1 year & 0.053 & $(0.224)$ & 0.062 & $(0.242)$ & 0.233 & $(0.423)$ \\
\hline 2 years & 0.062 & $(0.241)$ & 0.105 & $(0.307)$ & 0.150 & $(0.357)$ \\
\hline 3 years & 0.081 & $(0.274)$ & 0.177 & $(0.382)$ & 0.091 & $(0.287)$ \\
\hline 4 years & 0.086 & $(0.281)$ & 0.219 & $(0.413)$ & 0.056 & $(0.231)$ \\
\hline 5 years & 0.090 & $(0.286)$ & 0.146 & $(0.353)$ & 0.051 & $(0.219)$ \\
\hline $6-10$ years & 0.404 & $(0.491)$ & 0.199 & $(0.400)$ & 0.094 & $(0.292)$ \\
\hline $11-15$ years & 0.121 & $(0.326)$ & 0.034 & $(0.182)$ & 0.030 & $(0.171)$ \\
\hline $16-20$ years & 0.041 & $(0.198)$ & 0.014 & $(0.117)$ & 0.015 & $(0.122)$ \\
\hline$>20$ years & 0.023 & $(0.151)$ & 0.012 & $(0.108)$ & 0.008 & $(0.087)$ \\
\hline \multicolumn{7}{|l|}{ Province } \\
\hline Newfoundland & 0.081 & $(0.273)$ & 0.020 & $(0.140)$ & 0.028 & $(0.166)$ \\
\hline Prince Edward Island & 0.002 & $(0.043)$ & 0.004 & $(0.065)$ & 0.001 & $(0.037)$ \\
\hline Nova Scotia & 0.033 & $(0.178)$ & 0.031 & $(0.172)$ & 0.025 & $(0.157)$ \\
\hline New Brunswick & 0.023 & $(0.149)$ & 0.029 & $(0.169)$ & 0.036 & $(0.185)$ \\
\hline Ontario & 0.492 & $(0.500)$ & 0.376 & $(0.484)$ & 0.251 & $(0.433)$ \\
\hline Manitoba & 0.027 & $(0.161)$ & 0.044 & $(0.204)$ & 0.042 & $(0.201)$ \\
\hline Saskatchewan & 0.041 & $(0.198)$ & 0.057 & $(0.231)$ & 0.052 & $(0.221)$ \\
\hline Alberta & 0.187 & $(0.390)$ & 0.304 & $(0.460)$ & 0.416 & $(0.493)$ \\
\hline British Columbia & 0.109 & $(0.312)$ & 0.132 & $(0.339)$ & 0.141 & $(0.348)$ \\
\hline Territories & 0.006 & $(0.076)$ & 0.004 & $(0.063)$ & 0.008 & $(0.087)$ \\
\hline
\end{tabular}


Table 3 Summary statistics for long-term continuers, completers and discontinuers, 2007 (Continued)

\begin{tabular}{|c|c|c|c|c|c|c|}
\hline \multicolumn{7}{|l|}{ Detailed trade groups } \\
\hline Non-coded & 0.005 & $(0.072)$ & 0.012 & $(0.107)$ & 0.012 & $(0.109)$ \\
\hline Automotive service & 0.164 & $(0.371)$ & 0.137 & $(0.344)$ & 0.130 & $(0.337)$ \\
\hline Bricklayer/mason & 0.007 & $(0.082)$ & 0.007 & $(0.081)$ & 0.008 & $(0.088)$ \\
\hline Carpenter/Cabinet maker & 0.117 & $(0.322)$ & 0.065 & $(0.247)$ & 0.119 & $(0.324)$ \\
\hline Crane operator & 0.013 & $(0.113)$ & 0.017 & $(0.129)$ & 0.015 & $(0.120)$ \\
\hline Early childhood educator & 0.004 & $(0.066)$ & 0.006 & $(0.079)$ & 0.007 & $(0.086)$ \\
\hline Electrician & 0.144 & $(0.351)$ & 0.149 & $(0.356)$ & 0.139 & $(0.346)$ \\
\hline Electronics & 0.009 & $(0.096)$ & 0.007 & $(0.083)$ & 0.012 & $(0.109)$ \\
\hline Food service & 0.070 & $(0.254)$ & 0.044 & $(0.205)$ & 0.051 & $(0.220)$ \\
\hline Hairstylist - esthetician & 0.061 & $(0.238)$ & 0.099 & $(0.299)$ & 0.054 & $(0.226)$ \\
\hline Heavy duty equipment mechanic & 0.058 & $(0.234)$ & 0.073 & $(0.261)$ & 0.061 & $(0.239)$ \\
\hline Heavy equipment operator & 0.008 & $(0.087)$ & 0.001 & $(0.024)$ & 0.002 & $(0.040)$ \\
\hline Industry instrument technician & 0.012 & $(0.107)$ & 0.012 & $(0.109)$ & 0.029 & $(0.167)$ \\
\hline Interior finish & 0.010 & $(0.101)$ & 0.005 & $(0.072)$ & 0.007 & $(0.081)$ \\
\hline Lather & 0.007 & $(0.081)$ & 0.004 & $(0.061)$ & 0.007 & $(0.082)$ \\
\hline Machinist & 0.063 & $(0.243)$ & 0.063 & $(0.243)$ & 0.049 & $(0.216)$ \\
\hline Metal worker (other) & 0.017 & $(0.129)$ & 0.021 & $(0.145)$ & 0.017 & $(0.129)$ \\
\hline Millwright & 0.048 & $(0.213)$ & 0.056 & $(0.230)$ & 0.033 & $(0.179)$ \\
\hline Other & 0.027 & $(0.162)$ & 0.023 & $(0.151)$ & 0.028 & $(0.165)$ \\
\hline Partsperson & 0.004 & $(0.061)$ & 0.011 & $(0.105)$ & 0.008 & $(0.090)$ \\
\hline Plumber/pipefitter/steamfitt & 0.069 & $(0.254)$ & 0.086 & $(0.280)$ & 0.108 & $(0.311)$ \\
\hline Refrigeration \& air cond. mechanic & 0.017 & $(0.130)$ & 0.019 & $(0.136)$ & 0.016 & $(0.127)$ \\
\hline Roofer & 0.004 & $(0.062)$ & 0.003 & $(0.051)$ & 0.008 & $(0.088)$ \\
\hline Sheet metal worker & 0.025 & $(0.156)$ & 0.019 & $(0.136)$ & 0.023 & $(0.150)$ \\
\hline Welder & 0.039 & $(0.193)$ & 0.061 & $(0.240)$ & 0.057 & $(0.232)$ \\
\hline \multicolumn{7}{|l|}{ Peers in trade } \\
\hline Parents & 0.223 & $(0.416)$ & 0.188 & $(0.391)$ & 0.159 & $(0.366)$ \\
\hline Siblings & 0.331 & $(0.471)$ & 0.295 & $(0.456)$ & 0.281 & $(0.449)$ \\
\hline Friends & 0.393 & $(0.488)$ & 0.371 & $(0.483)$ & 0.415 & $(0.493)$ \\
\hline Co-workers & 0.217 & $(0.412)$ & 0.223 & $(0.416)$ & 0.224 & $(0.417)$ \\
\hline \multicolumn{7}{|c|}{ Various background/employment factors } \\
\hline Unemployment rate at end & 6.720 & $(3.307)$ & 6.424 & $(2.431)$ & 6.383 & $(2.804)$ \\
\hline Youth apprenticeship program & 0.109 & $(0.312)$ & 0.075 & $(0.264)$ & 0.108 & $(0.310)$ \\
\hline Trade in high school & 0.483 & $(0.500)$ & 0.503 & $(0.500)$ & 0.479 & $(0.500)$ \\
\hline Different language at home and work & 0.076 & $(0.264)$ & 0.062 & $(0.242)$ & 0.070 & $(0.255)$ \\
\hline Difficulty finding employer at start & 0.188 & $(0.391)$ & 0.179 & $(0.383)$ & 0.187 & $(0.390)$ \\
\hline Union member at beginning & 0.140 & $(0.347)$ & 0.151 & $(0.358)$ & 0.170 & $(0.376)$ \\
\hline Journeyperson present always & 0.798 & $(0.401)$ & 0.821 & $(0.383)$ & 0.802 & $(0.399)$ \\
\hline \multicolumn{7}{|l|}{ Type of training } \\
\hline No technical training & 0.481 & $(0.500)$ & 0.434 & $(0.496)$ & 0.695 & $(0.460)$ \\
\hline Long block release (> 2 weeks/year) & 0.300 & $(0.458)$ & 0.377 & $(0.485)$ & 0.214 & $(0.410)$ \\
\hline Short block release ( $1-2$ weeks/year) & 0.020 & $(0.141)$ & 0.018 & $(0.132)$ & 0.012 & $(0.107)$ \\
\hline Day release & 0.078 & $(0.268)$ & 0.069 & $(0.254)$ & 0.033 & $(0.177)$ \\
\hline
\end{tabular}


Table 3 Summary statistics for long-term continuers, completers and discontinuers, 2007 (Continued)

\begin{tabular}{|c|c|c|c|c|c|c|}
\hline Self-paced, distance ed., etc. & 0.074 & $(0.262)$ & 0.063 & $(0.242)$ & 0.031 & $(0.172)$ \\
\hline Full-time/full-year (high school or college) & 0.004 & $(0.063)$ & 0.003 & $(0.057)$ & 0.004 & $(0.061)$ \\
\hline Other training & 0.041 & $(0.199)$ & 0.034 & $(0.182)$ & 0.011 & $(0.106)$ \\
\hline \multicolumn{7}{|l|}{ Number of employers } \\
\hline 1 employer & 0.423 & $(0.494)$ & 0.534 & $(0.499)$ & 0.637 & $(0.481)$ \\
\hline 2 employers & 0.233 & $(0.422)$ & 0.218 & $(0.413)$ & 0.175 & $(0.380)$ \\
\hline 3 employers & 0.139 & $(0.346)$ & 0.107 & $(0.309)$ & 0.073 & $(0.261)$ \\
\hline 4 employers & 0.067 & $(0.250)$ & 0.050 & $(0.218)$ & 0.034 & $(0.182)$ \\
\hline$>4$ employers & 0.126 & $(0.332)$ & 0.088 & $(0.284)$ & 0.051 & $(0.220)$ \\
\hline Don't know \# of employers & 0.013 & $(0.113)$ & 0.003 & $(0.059)$ & 0.030 & $(0.171)$ \\
\hline \multicolumn{7}{|l|}{ Firm size } \\
\hline Less than 20 & 0.501 & $(0.500)$ & 0.472 & $(0.499)$ & 0.492 & $(0.500)$ \\
\hline 20-99 employees & 0.265 & $(0.442)$ & 0.303 & $(0.460)$ & 0.276 & $(0.447)$ \\
\hline 100-499 employees & 0.137 & $(0.343)$ & 0.149 & $(0.356)$ & 0.126 & $(0.331)$ \\
\hline 500 to 999 employess & 0.023 & $(0.150)$ & 0.027 & $(0.161)$ & 0.022 & $(0.148)$ \\
\hline > 999 employees & 0.038 & $(0.190)$ & 0.039 & $(0.194)$ & 0.036 & $(0.187)$ \\
\hline Don't know size & 0.037 & $(0.188)$ & 0.011 & $(0.103)$ & 0.047 & $(0.211)$ \\
\hline Sample size - unweighted & \multicolumn{2}{|c|}{4,706} & \multicolumn{2}{|c|}{14,694} & \multicolumn{2}{|c|}{2,539} \\
\hline Sample size - weighted & \multicolumn{2}{|c|}{16,703} & \multicolumn{2}{|c|}{46,206} & \multicolumn{2}{|c|}{9,439} \\
\hline Proportion of total & \multicolumn{2}{|c|}{0.231} & \multicolumn{2}{|c|}{0.639} & \multicolumn{2}{|c|}{0.130} \\
\hline
\end{tabular}

Completers experienced lower regional unemployment rates compared to LTCs (but slightly higher unemployment rates than discontinuers), and these rates were also less dispersed (i.e., lower standard deviations). Completers were less likely than discontinuers to be involved in a YAP, although they were more likely to have taken trade, vocational, or technical programs during high school. Completers were also less likely to have spoken a different language on the job than at home. ${ }^{\circ}$

The type of technical training undertaken is related to apprenticeship continuation. About $43 \%$ of completers had no technical training; nor did about $70 \%$ of discontinuers. The latter result is not surprising, since most discontinuers leave their programs within the first two years. The former result suggests that a large proportion of completers is challenging the exam without technical training or has completed the training before registering as apprentices. In terms of type of training, long-block release shows a greater association with completion than with continuation and discontinuation.

Completers are most likely to have worked for only one employer (rather than for multiple employers) during training. About one-half of all apprentices worked for firms with less than 20 employees; this proportion rose to about $77 \%$ when firms with up to 99 employees were included.

The regression results in the next section will offer more precise estimates of the relationship of these variables to completion probabilities.

\section{Multinomial probit results}

The results of the multinomial probit model are in Table 4. In each case, the coefficients are the marginal effects calculated at the means of the independent variables (or 
Table 4 Multinomial probit estimates for long-term continuers, completers, and discontinuers, 2007

\begin{tabular}{|c|c|c|c|c|c|c|c|c|c|}
\hline & \multicolumn{3}{|c|}{ (1) } & \multicolumn{3}{|c|}{ (2) } & \multicolumn{3}{|c|}{ (3) } \\
\hline & LTCs & Compl. & Disc. & LTCs & Compl. & Disc. & LTCs & Compl. & Disc. \\
\hline \multirow[t]{2}{*}{ Male } & $0.040 * * *$ & $-0.105^{* * *}$ & $0.065 * * *$ & $-0.025^{* * *}$ & $0.051 *$ & -0.025 & $-0.025^{* *}$ & 0.050 & -0.025 \\
\hline & {$[0.011]$} & {$[0.014]$} & {$[0.006]$} & {$[0.008]$} & {$[0.028]$} & {$[0.026]$} & {$[0.010]$} & {$[0.033]$} & {$[0.028]$} \\
\hline \multirow[t]{2}{*}{ Age in 2007} & $-0.038^{* * *}$ & $0.046^{* * *}$ & $-0.008^{* * *}$ & $-0.040^{* * *}$ & $0.050 * * *$ & $-0.010 * * *$ & $-0.035^{* * *}$ & $0.046^{* * *}$ & $-0.011^{* * *}$ \\
\hline & {$[0.003]$} & {$[0.004]$} & {$[0.002]$} & {$[0.002]$} & {$[0.005]$} & {$[0.003]$} & {$[0.001]$} & {$[0.003]$} & {$[0.003]$} \\
\hline \multirow[t]{2}{*}{ Age2/1000 } & $0.442 * * *$ & -0.554 *** & $0.112 * * *$ & $0.467 * * *$ & $-0.597^{* * *}$ & $0.131 * * *$ & $0.417 * * *$ & $-0.556 * * *$ & $0.140 * * *$ \\
\hline & {$[0.030]$} & {$[0.054]$} & {$[0.028]$} & {$[0.029]$} & {$[0.059]$} & {$[0.033]$} & {$[0.011]$} & {$[0.037]$} & {$[0.032]$} \\
\hline \multicolumn{10}{|c|}{ Marital status at end (married) } \\
\hline \multirow[t]{2}{*}{ Divorced } & 0.030 & $-0.081^{* * *}$ & $0.051 * * *$ & 0.029 & $-0.076^{* *}$ & $0.047^{* * *}$ & 0.027 & $-0.075 * * *$ & $0.048 * * *$ \\
\hline & {$[0.023]$} & {$[0.025]$} & {$[0.0064]$} & {$[0.024]$} & {$[0.031]$} & {$[0.010]$} & {$[0.022]$} & {$[0.028]$} & {$[0.009]$} \\
\hline \multirow[t]{2}{*}{ Single } & $-0.024 * *$ & $-0.025 * * *$ & $0.048 * * *$ & $-0.027^{* * *}$ & $-0.019 * *$ & $0.045 * * *$ & $-0.028^{* * *}$ & $-0.016^{* *}$ & $0.044 * * *$ \\
\hline & {$[0.0092]$} & {$[0.007]$} & {$[0.003]$} & {$[0.010]$} & {$[0.008]$} & {$[0.003]$} & {$[0.009]$} & {$[0.007]$} & {$[0.002]$} \\
\hline \multirow[t]{2}{*}{$\mathrm{Nb}$ of children $<18$} & $0.042 * * *$ & $-0.046 * * *$ & $0.004 * * *$ & $0.043 * * *$ & $-0.047^{* * *}$ & $0.004 * * *$ & $0.042^{* * *}$ & $-0.045^{* * *}$ & $0.003 * * *$ \\
\hline & {$[0.002]$} & {$[0.002]$} & {$[0.001]$} & {$[0.002]$} & {$[0.002]$} & {$[0.001]$} & {$[0.002]$} & {$[0.003]$} & {$[0.001]$} \\
\hline \multirow[t]{2}{*}{ Aboriginal } & $0.059 * * *$ & $-0.086^{* * *}$ & $0.027 * * *$ & $0.054 * * *$ & $-0.076^{* * *}$ & $0.023 * * *$ & $0.055^{* * *}$ & $-0.075^{* * *}$ & $0.020 * * *$ \\
\hline & {$[0.017]$} & {$[0.012]$} & {$[0.008]$} & {$[0.018]$} & {$[0.015]$} & {$[0.007]$} & {$[0.015]$} & {$[0.001]$} & {$[0.008]$} \\
\hline \multirow[t]{2}{*}{ Visible minorities } & $0.071 * * *$ & $-0.055^{* * *}$ & -0.016 & $0.075^{* *}$ & $-0.070^{* * *}$ & -0.005 & $0.069^{* * *}$ & $-0.062 * * *$ & -0.008 \\
\hline & {$[0.024]$} & {$[0.009]$} & {$[0.017]$} & {$[0.031]$} & {$[0.022]$} & {$[0.012]$} & {$[0.027]$} & {$[0.019]$} & {$[0.008]$} \\
\hline \multirow[t]{2}{*}{ Immigrant } & 0.005 & 0.002 & $-0.006^{* * *}$ & 0.008 & -0.002 & $-0.006 * * *$ & -0.001 & 0.014 & $-0.013 *$ \\
\hline & {$[0.012]$} & {$[0.012]$} & {$[0.002]$} & {$[0.012]$} & {$[0.013]$} & {$[0.002]$} & {$[0.010]$} & {$[0.011]$} & {$[0.008]$} \\
\hline \multirow[t]{2}{*}{ Immigrant father } & $0.022 * *$ & $-0.020 * *$ & -0.002 & $0.024 * * *$ & $-0.021^{* * *}$ & -0.003 & $0.025^{* * *}$ & $-0.022 * * *$ & -0.003 \\
\hline & {$[0.009]$} & {$[0.009]$} & {$[0.009]$} & {$[0.009]$} & {$[0.007]$} & {$[0.009]$} & {$[0.008]$} & {$[0.006]$} & {$[0.007]$} \\
\hline
\end{tabular}


Table 4 Multinomial probit estimates for long-term continuers, completers, and discontinuers, 2007 (Continued)

\begin{tabular}{|c|c|c|c|c|c|c|c|c|c|}
\hline \multirow[t]{2}{*}{ Immigrant mother } & -0.003 & $-0.007^{*}$ & 0.010 & -0.001 & $-0.008^{* *}$ & 0.010 & 0.001 & -0.008 & 0.007 \\
\hline & {$[0.016]$} & {$[0.004]$} & {$[0.015]$} & {$[0.017]$} & {$[0.0039]$} & {$[0.016]$} & {$[0.017]$} & {$[0.005]$} & {$[0.014]$} \\
\hline \multirow[t]{2}{*}{ Disability at beginning } & $0.086^{* * *}$ & $-0.101 * * *$ & 0.015 & $0.086^{* * *}$ & $-0.105^{* * *}$ & 0.019 & $0.072^{* * *}$ & $-0.091^{* * *}$ & 0.019 \\
\hline & {$[0.013]$} & {$[0.024]$} & [0.013] & {$[0.016]$} & {$[0.029]$} & {$[0.015]$} & {$[0.015]$} & {$[0.028]$} & {$[0.015]$} \\
\hline \multicolumn{10}{|l|}{ Education (high school) } \\
\hline \multirow[t]{2}{*}{ Less than high school } & $0.063 * * *$ & $-0.081 * * *$ & $0.018^{* *}$ & $0.062 * * *$ & $-0.086^{* * *}$ & $0.024 * * *$ & $0.061 * * *$ & $-0.084 * * *$ & $0.023 * * *$ \\
\hline & {$[0.017]$} & {$[0.020]$} & {$[0.008]$} & {$[0.019]$} & {$[0.023]$} & {$[0.009]$} & {$[0.020]$} & {$[0.024]$} & {$[0.009]$} \\
\hline \multirow[t]{2}{*}{ Trade-vocational } & -0.001 & 0.012 & -0.011 & 0.005 & 0.000 & -0.005 & 0.003 & 0.003 & -0.005 \\
\hline & {$[0.024]$} & {$[0.030]$} & {$[0.009]$} & {$[0.022]$} & {$[0.025]$} & {$[0.007]$} & {$[0.018]$} & {$[0.021]$} & {$[0.008]$} \\
\hline \multirow[t]{2}{*}{ College } & -0.010 & -0.001 & 0.012 & $-0.011^{* *}$ & 0.004 & 0.007 & -0.007 & -0.001 & 0.008 \\
\hline & {$[0.006]$} & {$[0.012]$} & {$[0.008]$} & {$[0.005]$} & {$[0.007]$} & {$[0.007]$} & {$[0.005]$} & {$[0.005]$} & {$[0.006]$} \\
\hline \multirow[t]{2}{*}{ University } & -0.021 & 0.015 & 0.006 & $-0.030 *$ & $0.031 * *$ & -0.001 & $-0.029 * *$ & $0.027 * * *$ & 0.002 \\
\hline & {$[0.016]$} & {$[0.013]$} & {$[0.006]$} & {$[0.017]$} & {$[0.015]$} & {$[0.004]$} & {$[0.014]$} & {$[0.010]$} & {$[0.006]$} \\
\hline \multirow[t]{2}{*}{ Unknown } & $0.203 * *$ & $-0.141 * *$ & -0.062 & $0.234 * *$ & $-0.179 * * *$ & -0.055 & $0.211 * * *$ & $-0.158^{* * *}$ & -0.054 \\
\hline & [0.093] & {$[0.071]$} & [0.039] & [0.092] & {$[0.067]$} & {$[0.043]$} & [0.081] & {$[0.053]$} & {$[0.040]$} \\
\hline \multicolumn{10}{|c|}{ Number of years in program ( 4 years) } \\
\hline \multirow[t]{2}{*}{ Less than 1 year } & -0.034 & $-0.543 * * *$ & $0.577^{* * *}$ & $-0.043 *$ & $-0.563 * * *$ & $0.607 * * *$ & -0.014 & $-0.542 * * *$ & $0.555^{* * *}$ \\
\hline & {$[0.023]$} & {$[0.009]$} & {$[0.025]$} & {$[0.022]$} & {$[0.012]$} & {$[0.019]$} & {$[0.031]$} & {$[0.014]$} & {$[0.030]$} \\
\hline \multirow[t]{2}{*}{1 year } & -0.004 & $-0.419 * * *$ & $0.422^{* * *}$ & -0.008 & $-0.457 * * *$ & $0.465 * * *$ & 0.011 & $-0.439 * * *$ & $0.428 * * *$ \\
\hline & {$[0.036]$} & {$[0.024]$} & {$[0.030]$} & {$[0.035]$} & {$[0.024]$} & {$[0.021]$} & {$[0.042]$} & {$[0.022]$} & {$[0.030]$} \\
\hline \multirow[t]{2}{*}{2 years } & 0.007 & $-0.234 * * *$ & $0.226^{* * *}$ & 0.006 & $-0.251 * * *$ & $0.246 * * *$ & 0.013 & $-0.245^{* * *}$ & $0.232 * * *$ \\
\hline & {$[0.017]$} & {$[0.014]$} & [0.013] & {$[0.018]$} & {$[0.017]$} & {$[0.011]$} & {$[0.021]$} & {$[0.018]$} & {$[0.012]$} \\
\hline \multirow[t]{2}{*}{3 years } & 0.006 & $-0.076^{* * *}$ & $0.069 * * *$ & 0.005 & $-0.082 * * *$ & $0.076^{* * *}$ & 0.006 & $-0.079^{* * *}$ & $0.073^{* * *}$ \\
\hline & {$[0.007]$} & {$[0.020]$} & {$[0.020]$} & {$[0.008]$} & {$[0.014]$} & {$[0.016]$} & {$[0.007]$} & {$[0.016]$} & [0.018] \\
\hline
\end{tabular}


Table 4 Multinomial probit estimates for long-term continuers, completers, and discontinuers, 2007 (Continued)

\begin{tabular}{|c|c|c|c|c|c|c|c|c|c|}
\hline \multirow[t]{2}{*}{5 years } & $0.073^{* *}$ & $-0.090^{* * *}$ & 0.017 & $0.073^{* *}$ & $-0.090 * * *$ & 0.017 & $0.063^{* * *}$ & $-0.083 * * *$ & 0.019 \\
\hline & {$[0.030]$} & {$[0.021]$} & {$[0.020]$} & {$[0.029]$} & {$[0.018]$} & {$[0.019]$} & {$[0.023]$} & {$[0.012]$} & {$[0.018]$} \\
\hline \multirow[t]{2}{*}{$6-10$ years } & $0.300 * * *$ & $-0.307 * * *$ & 0.007 & $0.299 * * *$ & $-0.307^{* * *}$ & 0.008 & $0.274 * * *$ & $-0.287^{* * *}$ & 0.013 \\
\hline & {$[0.019]$} & {$[0.011]$} & {$[0.010]$} & {$[0.018]$} & {$[0.011]$} & {$[0.010]$} & {$[0.014]$} & {$[0.009]$} & {$[0.008]$} \\
\hline \multirow[t]{2}{*}{$11-15$ years } & $0.422 * * *$ & $-0.449 * * *$ & $0.027^{* * *}$ & $0.421^{* * *}$ & $-0.449 * * *$ & $0.027^{* * *}$ & $0.394^{* * *}$ & $-0.430 * * *$ & $0.035^{* * *}$ \\
\hline & {$[0.022]$} & {$[0.027]$} & {$[0.010]$} & {$[0.022]$} & {$[0.025]$} & {$[0.011]$} & {$[0.034]$} & {$[0.033]$} & {$[0.011]$} \\
\hline \multirow[t]{2}{*}{$16-20$ years } & $0.381 * * *$ & $-0.434^{* * *}$ & $0.052 * *$ & $0.382^{* * *}$ & $-0.434^{* * *}$ & $0.052^{* *}$ & $0.349^{* * *}$ & $-0.407 * * *$ & $0.058 * *$ \\
\hline & {$[0.041]$} & {$[0.023]$} & {$[0.026]$} & {$[0.040]$} & {$[0.022]$} & {$[0.026]$} & {$[0.054]$} & {$[0.033]$} & {$[0.028]$} \\
\hline \multirow[t]{2}{*}{$>20$ years } & $0.308^{* * *}$ & $-0.326^{* * *}$ & 0.018 & $0.303^{* * *}$ & $-0.325 * * *$ & 0.022 & $0.284^{* * *}$ & $-0.304 * * *$ & 0.021 \\
\hline & {$[0.020]$} & {$[0.017]$} & {$[0.023]$} & {$[0.023]$} & {$[0.014]$} & {$[0.023]$} & {$[0.027]$} & {$[0.012]$} & {$[0.025]$} \\
\hline \multicolumn{10}{|l|}{ Province (Ontario) } \\
\hline \multirow[t]{2}{*}{ Newfoundland } & $0.167^{* * *}$ & $-0.234^{* * *}$ & $0.067^{* * *}$ & $0.148^{* * *}$ & $-0.229 * * *$ & $0.081^{* * *}$ & $0.457^{* * *}$ & $-0.476^{* * *}$ & 0.018 \\
\hline & {$[0.003]$} & {$[0.005]$} & {$[0.007]$} & {$[0.007]$} & {$[0.007]$} & {$[0.010]$} & {$[0.140]$} & {$[0.120]$} & {$[0.025]$} \\
\hline \multirow[t]{2}{*}{ Prince Edward Island } & $-0.138 * * *$ & $0.179 * * *$ & $-0.040^{* * *}$ & $-0.147^{* * *}$ & $0.194 * * *$ & $-0.047^{* * *}$ & -0.072 & $0.116^{* *}$ & $-0.043^{* * *}$ \\
\hline & {$[0.002]$} & {$[0.005]$} & {$[0.003]$} & {$[0.001]$} & {$[0.003]$} & {$[0.004]$} & {$[0.047]$} & {$[0.051]$} & {$[0.006]$} \\
\hline \multirow[t]{2}{*}{ Nova Scotia } & $-0.075 * * *$ & $0.020^{* * *}$ & $0.054^{* * *}$ & $-0.080^{* * *}$ & $0.035^{* * *}$ & $0.045 * * *$ & -0.005 & -0.042 & $0.048 * * *$ \\
\hline & {$[0.002]$} & {$[0.007]$} & {$[0.005]$} & {$[0.003]$} & {$[0.006]$} & {$[0.005]$} & {$[0.035]$} & {$[0.040]$} & {$[0.007]$} \\
\hline \multirow[t]{2}{*}{ New Brunswick } & $-0.090 * * *$ & $0.016^{* *}$ & $0.074 * * *$ & $-0.097 * * *$ & $0.032 * * *$ & $0.064 * * *$ & -0.031 & -0.033 & $0.064 * * *$ \\
\hline & {$[0.001]$} & {$[0.007]$} & {$[0.007]$} & {$[0.002]$} & {$[0.007]$} & {$[0.007]$} & {$[0.028]$} & {$[0.036]$} & {$[0.010]$} \\
\hline \multirow[t]{2}{*}{ Manitoba } & $-0.120 * * *$ & $0.066 * * *$ & $0.055^{* * *}$ & $-0.121^{* * *}$ & $0.061 * * *$ & $0.061 * * *$ & $-0.140 * * *$ & $0.090 * * *$ & $0.051^{* * *}$ \\
\hline & {$[0.001]$} & {$[0.002]$} & {$[0.002]$} & {$[0.003]$} & {$[0.003]$} & {$[0.004]$} & {$[0.011]$} & {$[0.013]$} & {$[0.004]$} \\
\hline \multirow[t]{2}{*}{ Saskatchewan } & $-0.100 * * *$ & $0.052 * * *$ & $0.048 * * *$ & $-0.101 * * *$ & $0.054 * * *$ & $0.046^{* * *}$ & $-0.114^{* * *}$ & $0.070 * * *$ & $0.044 * * *$ \\
\hline & {$[0.001]$} & {$[0.005]$} & {$[0.005]$} & {$[0.003]$} & {$[0.002]$} & {$[0.0051]$} & {$[0.013]$} & {$[0.012]$} & {$[0.004]$} \\
\hline
\end{tabular}


Table 4 Multinomial probit estimates for long-term continuers, completers, and discontinuers, 2007 (Continued)

\begin{tabular}{|c|c|c|c|c|c|c|c|c|c|}
\hline \multirow[t]{2}{*}{ Alberta } & $-0.134 * * *$ & $0.054^{* * *}$ & $0.080^{* * *}$ & $-0.134 * * *$ & $0.055 * * *$ & $0.080 * * *$ & $-0.173 * * *$ & $0.096 * * *$ & $0.077 * * *$ \\
\hline & {$[0.003]$} & {$[0.002]$} & {$[0.003]$} & {$[0.008]$} & {$[0.008]$} & {$[0.003]$} & {$[0.025]$} & {$[0.028]$} & {$[0.006]$} \\
\hline \multirow[t]{2}{*}{ British Columbia } & $-0.057 * * *$ & $0.025^{* * *}$ & $0.032 * * *$ & $-0.072 * * *$ & $0.050 * * *$ & $0.022 * * *$ & $-0.056^{* * *}$ & $0.033 * * *$ & $0.023 * * *$ \\
\hline & {$[0.003]$} & {$[0.001]$} & {$[0.002]$} & {$[0.006]$} & {$[0.004]$} & {$[0.003]$} & {$[0.004]$} & {$[0.004]$} & {$[0.002]$} \\
\hline \multirow[t]{2}{*}{ Territories } & $-0.051 *$ & $-0.096 * * *$ & $0.147 * * *$ & $-0.064 * * *$ & -0.064 & $0.129 * *$ & $-0.053 *$ & $-0.085^{* *}$ & $0.138^{* *}$ \\
\hline & {$[0.028]$} & {$[0.031]$} & {$[0.057]$} & {$[0.021]$} & {$[0.045]$} & {$[0.064]$} & {$[0.029]$} & {$[0.035]$} & {$[0.061]$} \\
\hline \multicolumn{10}{|c|}{ Trade groups (Carpenter/cabinet maker) } \\
\hline \multirow[t]{2}{*}{ Non-coded } & & & & $-0.158^{* * *}$ & $0.184 * * *$ & -0.026 & $-0.154^{* * *}$ & $0.181 * * *$ & -0.028 \\
\hline & & & & {$[0.022]$} & {$[0.058]$} & {$[0.036]$} & {$[0.023]$} & {$[0.057]$} & {$[0.035]$} \\
\hline \multirow[t]{2}{*}{ Automotive service } & & & & $-0.081^{* * *}$ & $0.107^{* * *}$ & $-0.026^{* *}$ & $-0.080^{* * *}$ & $0.104 * * *$ & $-0.025 * *$ \\
\hline & & & & {$[0.023]$} & {$[0.018]$} & {$[0.012]$} & {$[0.020]$} & {$[0.013]$} & {$[0.012]$} \\
\hline \multirow[t]{2}{*}{ Bricklayer/mason } & & & & $-0.090 * * *$ & $0.116 * * *$ & -0.026 & $-0.089 * * *$ & $0.118^{* * *}$ & -0.029 \\
\hline & & & & {$[0.018]$} & {$[0.033]$} & {$[0.022]$} & {$[0.019]$} & {$[0.034]$} & {$[0.021]$} \\
\hline \multirow[t]{2}{*}{ Crane operator } & & & & $-0.091 * * *$ & $0.172 * * *$ & $-0.081 * * *$ & $-0.086^{* * *}$ & $0.167 * * *$ & $-0.081 * * *$ \\
\hline & & & & {$[0.016]$} & {$[0.017]$} & {$[0.005]$} & {$[0.016]$} & {$[0.018]$} & {$[0.005]$} \\
\hline \multirow[t]{2}{*}{ Early childhood educator } & & & & $-0.149 * * *$ & $0.174 * * *$ & -0.024 & $-0.145^{* * *}$ & $0.176^{* * *}$ & -0.031 \\
\hline & & & & {$[0.005]$} & {$[0.025]$} & {$[0.023]$} & {$[0.004]$} & {$[0.023]$} & {$[0.021]$} \\
\hline \multirow[t]{2}{*}{ Electrician } & & & & $-0.084 * * *$ & $0.106 * * *$ & -0.023 & $-0.082 * * *$ & $0.101 * * *$ & -0.019 \\
\hline & & & & {$[0.020]$} & {$[0.023]$} & {$[0.016]$} & {$[0.021]$} & {$[0.023]$} & {$[0.018]$} \\
\hline \multirow[t]{2}{*}{ Electronics } & & & & 0.012 & 0.030 & $-0.042^{* * *}$ & 0.032 & 0.009 & $-0.041 * * *$ \\
\hline & & & & {$[0.030]$} & {$[0.029]$} & {$[0.006]$} & {$[0.023]$} & {$[0.024]$} & {$[0.007]$} \\
\hline \multirow[t]{2}{*}{ Food service } & & & & -0.013 & $0.072 *$ & $-0.059 * * *$ & -0.012 & $0.068 *$ & $-0.057 * * *$ \\
\hline & & & & {$[0.032]$} & {$[0.039]$} & {$[0.019]$} & [0.027] & {$[0.036]$} & {$[0.019]$} \\
\hline
\end{tabular}


Table 4 Multinomial probit estimates for long-term continuers, completers, and discontinuers, 2007 (Continued)

\begin{tabular}{|c|c|c|c|c|c|c|}
\hline \multirow[t]{2}{*}{ Hairstylist - esthetician } & $-0.165 * * *$ & $0.274 * * *$ & $-0.109 * * *$ & $-0.166 * * *$ & $0.273 * * *$ & $-0.107 * * *$ \\
\hline & {$[0.011]$} & {$[0.014]$} & {$[0.007]$} & {$[0.008]$} & {$[0.011]$} & {$[0.007]$} \\
\hline \multirow[t]{2}{*}{ Heavy duty equipment mechanic } & $-0.098 * * *$ & $0.138^{* * *}$ & $-0.040 * * *$ & $-0.095 * * *$ & $0.131^{* * *}$ & $-0.036^{* * *}$ \\
\hline & {$[0.031]$} & {$[0.033]$} & {$[0.013]$} & [0.029] & {$[0.033]$} & [0.013] \\
\hline \multirow[t]{2}{*}{ Heavy equipment operator } & $0.237^{*}$ & $-0.193 *$ & $-0.044 * * *$ & $0.234 * *$ & $-0.183 * *$ & $-0.051^{* * *}$ \\
\hline & {$[0.13]$} & {$[0.11]$} & {$[0.016]$} & {$[0.110]$} & {$[0.093]$} & {$[0.014]$} \\
\hline \multirow[t]{2}{*}{ Industry instrument technician } & -0.033 & 0.024 & 0.009 & -0.031 & 0.031 & 0.000 \\
\hline & {$[0.029]$} & {$[0.029]$} & {$[0.013]$} & {$[0.027]$} & {$[0.024]$} & {$[0.012]$} \\
\hline \multirow[t]{2}{*}{ Interior finish } & 0.033 & 0.009 & -0.042 & 0.022 & 0.024 & $-0.046^{*}$ \\
\hline & {$[0.088]$} & [0.11] & {$[0.026]$} & {$[0.095]$} & {$[0.120]$} & {$[0.026]$} \\
\hline \multirow[t]{2}{*}{ Lather } & 0.001 & -0.002 & 0.001 & 0.019 & -0.009 & -0.009 \\
\hline & {$[0.035]$} & {$[0.031]$} & {$[0.017]$} & {$[0.028]$} & {$[0.024]$} & {$[0.019]$} \\
\hline \multirow[t]{2}{*}{ Machinist } & $-0.079 * * *$ & $0.100 * * *$ & $-0.022 * *$ & $-0.075 * * *$ & $0.091 * * *$ & -0.017 \\
\hline & {$[0.016]$} & {$[0.012]$} & {$[0.011]$} & {$[0.012]$} & {$[0.009]$} & [0.012] \\
\hline \multirow[t]{2}{*}{ Metal worker (other) } & $-0.093 * * *$ & $0.139 * * *$ & $-0.047^{* * *}$ & $-0.089 * * *$ & $0.135 * * *$ & $-0.046 * * *$ \\
\hline & {$[0.010]$} & {$[0.021]$} & {$[0.018]$} & {$[0.012]$} & {$[0.023]$} & {$[0.017]$} \\
\hline \multirow[t]{2}{*}{ Millwright } & $-0.093 * * *$ & $0.140 * * *$ & $-0.047^{* * *}$ & $-0.085 * * *$ & $0.129 * * *$ & $-0.044 * * *$ \\
\hline & {$[0.022]$} & {$[0.022]$} & {$[0.007]$} & {$[0.020]$} & {$[0.021]$} & {$[0.010]$} \\
\hline \multirow[t]{2}{*}{ Other } & $-0.036 *$ & $0.078 * * *$ & $-0.042 * * *$ & -0.036 & $0.079 * * *$ & $-0.043 * * *$ \\
\hline & {$[0.018]$} & {$[0.019]$} & {$[0.010]$} & {$[0.024]$} & {$[0.023]$} & {$[0.010]$} \\
\hline \multirow[t]{2}{*}{ Partsperson } & $-0.137 * * *$ & $0.209 * * *$ & $-0.072 * * *$ & $-0.134 * * *$ & $0.204^{* * *}$ & $-0.070 * * *$ \\
\hline & {$[0.012]$} & {$[0.0044]$} & {$[0.012]$} & {$[0.009]$} & {$[0.005]$} & {$[0.011]$} \\
\hline \multirow[t]{2}{*}{ Plumber/pipefitter/steamfitter } & $-0.102 * * *$ & $0.101^{* * *}$ & 0.001 & $-0.098 * * *$ & $0.097 * * *$ & 0.002 \\
\hline & {$[0.021]$} & {$[0.033]$} & {$[0.015]$} & {$[0.020]$} & {$[0.032]$} & {$[0.016]$} \\
\hline
\end{tabular}


Table 4 Multinomial probit estimates for long-term continuers, completers, and discontinuers, 2007 (Continued)

\begin{tabular}{|c|c|c|c|c|c|c|}
\hline \multirow[t]{2}{*}{ Refrigeration \& air cond. mechanic } & $-0.096 * * *$ & $0.107 * * *$ & -0.011 & $-0.087^{* * *}$ & $0.096 * * *$ & -0.009 \\
\hline & {$[0.013]$} & {$[0.029]$} & {$[0.022]$} & {$[0.016]$} & {$[0.031]$} & {$[0.021]$} \\
\hline \multirow[t]{2}{*}{ Roofer } & -0.053 & 0.018 & 0.035 & -0.063 & 0.038 & 0.025 \\
\hline & {$[0.060]$} & {$[0.035]$} & {$[0.057]$} & {$[0.051]$} & {$[0.032]$} & {$[0.049]$} \\
\hline \multirow[t]{2}{*}{ Sheet metal worker } & -0.044 & $0.0502^{* *}$ & -0.007 & -0.033 & 0.041 & -0.007 \\
\hline & {$[0.028]$} & {$[0.025]$} & {$[0.020]$} & {$[0.031]$} & {$[0.028]$} & {$[0.021]$} \\
\hline \multirow[t]{2}{*}{ Welder } & $-0.105^{* * *}$ & $0.163 * * *$ & $-0.058^{* * *}$ & $-0.100 * * *$ & $0.155^{* * *}$ & $-0.055^{* * *}$ \\
\hline & {$[0.010$} & {$[0.014]$} & {$[0.010]$} & [0.009] & {$[0.014]$} & {$[0.010]$} \\
\hline \multicolumn{7}{|l|}{ Peers in trade (no peers in trade) } \\
\hline \multirow[t]{2}{*}{ Parents } & & & & $0.021 * * *$ & -0.002 & $-0.018 * * *$ \\
\hline & & & & {$[0.007]$} & {$[0.006]$} & {$[0.003]$} \\
\hline \multirow[t]{2}{*}{ Siblings } & & & & 0.010 & -0.003 & $-0.007 * *$ \\
\hline & & & & {$[0.008]$} & {$[0.010]$} & {$[0.003]$} \\
\hline \multirow[t]{2}{*}{ Friends } & & & & $0.016 *$ & $-0.027 * *$ & $0.012 * *$ \\
\hline & & & & [0.009] & {$[0.013]$} & {$[0.005]$} \\
\hline \multirow[t]{2}{*}{ Co-workers } & & & & 0.003 & 0.004 & -0.007 \\
\hline & & & & [0.012] & {$[0.008]$} & {$[0.005]$} \\
\hline \multicolumn{7}{|c|}{ Various backgroud/employment factors } \\
\hline \multirow[t]{2}{*}{ Unemployment rate at end } & & & & $-0.025 * *$ & $0.025 *$ & 0.000 \\
\hline & & & & [0.013] & {$[0.013]$} & {$[0.002]$} \\
\hline \multirow[t]{2}{*}{ Youth apprenticeship program } & & & & $0.049 * * *$ & $-0.048 * * *$ & -0.001 \\
\hline & & & & {$[0.010]$} & {$[0.006]$} & {$[0.008]$} \\
\hline \multirow[t]{2}{*}{ Trade in high school } & & & & 0.003 & -0.008 & 0.005 \\
\hline & & & & {$[0.004]$} & {$[0.013]$} & [0.009] \\
\hline
\end{tabular}


Table 4 Multinomial probit estimates for long-term continuers, completers, and discontinuers, 2007 (Continued)

\begin{tabular}{|c|c|c|c|}
\hline \multirow[t]{2}{*}{ Different language at home and work } & 0.017 & $-0.045 * * *$ & 0.028 \\
\hline & {$[0.019]$} & {$[0.012]$} & {$[0.024]$} \\
\hline \multirow[t]{2}{*}{ Difficulty finding employer at start } & 0.003 & -0.011 & 0.007 \\
\hline & {$[0.012]$} & {$[0.014]$} & {$[0.007]$} \\
\hline \multirow[t]{2}{*}{ Union member at beginning } & -0.027 & 0.009 & $0.018 * * *$ \\
\hline & {$[0.018]$} & {$[0.020]$} & {$[0.006]$} \\
\hline \multirow[t]{2}{*}{ Journey person present always } & $-0.007 * *$ & $0.012 * * *$ & -0.005 \\
\hline & {$[0.003]$} & {$[0.004]$} & {$[0.004]$} \\
\hline \multicolumn{4}{|l|}{ Type of training (no training) } \\
\hline \multirow[t]{2}{*}{ Long block release (>2 weeks/year) } & $-0.040 * * *$ & $0.091 * * *$ & $-0.051 * *$ \\
\hline & {$[0.006]$} & {$[0.013]$} & {$[0.007]$} \\
\hline \multirow[t]{2}{*}{ Short block release (1-2 weeks/year) } & 0.019 & 0.026 & $-0.044 * *$ \\
\hline & {$[0.027]$} & {$[0.028]$} & {$[0.009]$} \\
\hline \multirow[t]{2}{*}{ Day release } & -0.001 & $0.048 * * *$ & $-0.047^{* *}$ \\
\hline & {$[0.007]$} & {$[0.014]$} & {$[0.014]$} \\
\hline \multirow[t]{2}{*}{ Self-paced, distance ed., etc. } & 0.008 & $0.037^{* *}$ & $-0.045 * *$ \\
\hline & {$[0.009]$} & {$[0.015]$} & {$[0.008]$} \\
\hline \multirow[t]{2}{*}{ Full-time/full-year (high school or college) } & -0.031 & 0.044 & -0.012 \\
\hline & {$[0.023]$} & {$[0.043]$} & {$[0.040]$} \\
\hline \multirow[t]{2}{*}{ Other training } & -0.004 & $0.066 * * *$ & $-0.062 * *$ \\
\hline & {$[0.013]$} & {$[0.015]$} & {$[0.004]$} \\
\hline \multicolumn{4}{|l|}{ Number of employers (1 employer) } \\
\hline \multirow[t]{2}{*}{2 employers } & $0.045^{* * *}$ & $-0.034^{* *}$ & -0.011 \\
\hline & {$[0.008]$} & {$[0.016]$} & {$[0.009]$} \\
\hline
\end{tabular}


Table 4 Multinomial probit estimates for long-term continuers, completers, and discontinuers, 2007 (Continued)

\begin{tabular}{|c|c|c|c|c|c|}
\hline \multirow[t]{2}{*}{3 employers } & & & $0.051 * * *$ & $-0.043 * *$ & -0.008 \\
\hline & & & {$[0.007]$} & {$[0.018]$} & {$[0.015]$} \\
\hline \multirow[t]{2}{*}{4 employers } & & & $0.056^{* * *}$ & $-0.052 * * *$ & -0.004 \\
\hline & & & {$[0.013]$} & {$[0.011]$} & {$[0.013]$} \\
\hline \multirow[t]{2}{*}{$>4$ employers } & & & $0.047 * * *$ & $-0.028 * * *$ & $-0.019 * *$ \\
\hline & & & {$[0.013]$} & {$[0.009]$} & {$[0.009]$} \\
\hline \multirow[t]{2}{*}{ Don't know \# of employers } & & & 0.070 & $-0.183 * * *$ & $0.113^{* * *}$ \\
\hline & & & {$[0.051]$} & {$[0.030]$} & {$[0.028]$} \\
\hline \multicolumn{6}{|l|}{ Firm size (less than 20) } \\
\hline \multirow[t]{2}{*}{ 20-99 employees } & & & $-0.020 * * *$ & $0.031 * * *$ & -0.011 \\
\hline & & & {$[0.004]$} & {$[0.007]$} & {$[0.007]$} \\
\hline \multirow[t]{2}{*}{ 100-499 employees } & & & -0.001 & $0.020 * * *$ & $-0.018^{* *}$ \\
\hline & & & {$[0.007]$} & {$[0.004]$} & {$[0.009]$} \\
\hline \multirow[t]{2}{*}{500 to 999 employess } & & & -0.006 & 0.024 & -0.018 \\
\hline & & & {$[0.025]$} & {$[0.021]$} & {$[0.011]$} \\
\hline \multirow[t]{2}{*}{ > 999 employees } & & & 0.012 & 0.003 & -0.015 \\
\hline & & & {$[0.034]$} & {$[0.018]$} & {$[0.020]$} \\
\hline \multirow[t]{2}{*}{ Don't know size } & & & $0.207^{* * *}$ & $-0.228 * * *$ & 0.021 \\
\hline & & & {$[0.027]$} & {$[0.041]$} & {$[0.018]$} \\
\hline Observations & 21939 & 21939 & & 21939 & \\
\hline
\end{tabular}

Notes: Omitted variables are in parentheses. Standard errors in brackets. ${ }^{* *} p<0.01,{ }^{* *} p<0.05,{ }^{*} p<0.1$. 
by changing the indicator variable from zero to one). In what follows we will concentrate on completion behaviour, since this is the outcome of most interest. The marginal effects on long-term continuation and on discontinuation are also included in this table, although these outcomes will not be discussed in depth.

It is noted again that the model is built up in a stepwise fashion, beginning with basic demographic information, to which are subsequently added a variety of regional and job-related variables in blocks. ${ }^{\mathrm{p}}$ The results discussed below correspond to the third, and final, model in Table 4. The first two models in the table are included for comparison purposes. The results are all robust to the inclusion of additional variables as the model is built up in stepwise fashion. In all cases, the dependent variable is the apprenticeship status at the time of the 2007 survey: long-term continuer (or LTC), completer, or discontinuer.

\section{Demographic characteristics}

In Table 4, males are statistically no more likely than females to complete their programs. This is largely owing to the number of women in the hairstylist-esthetician trade, where programs are relatively short and completion rates high. ${ }^{\mathrm{q}}$ Age is positively related to completion, but at a declining rate. Specifically, a quick calculation reveals that the probability of completion peaks at about age 41 and declines thereafter. This seems reasonable given that apprentices tend to start their programs later in life and that many take a long time to complete (Table 3). These estimates also control for length of time in the apprenticeship program; this result is therefore a net age effect. Being divorced or single at the end of the program is negatively related to program completion. Having children tends to reduce the probability of completion and to increase the probability of being a LTC.

The data in Table 4 show that non-Aboriginals ${ }^{\mathrm{r}}$ and individuals who do not belong to a visible minority (the excluded group) are more likely to complete. Trendle (2007) finds similar evidence for non-Aboriginal Australians in Queensland who also have a lower probability of canceling apprenticeship contracts compared to the Aboriginal population. This result is also in accord with Bilginsoy's (2003) evidence for the US regarding minorities. Immigrant status does not appear to be a determinant of completion. ${ }^{\mathrm{S}}$ Having an activity limitation at the beginning of the program (that has lasted or was expected to last for six months or longer) is negatively related to completion. Given the probabilities of being in any of these states, these marginal effects are large.

\section{Education prior to program commencement and number of years in program}

Table 4 addresses the effects of education prior to registering for the apprenticeship program. The general pattern here is that completion rates are significantly different from zero at both tails of the education distribution. Someone with less than high school is 8.4 percentage points less likely to have completed than someone with a high school education. Those with at least some university training, by contrast, have a positive 2.7 percentage point completion differential relative to high school graduates. Those with trade-vocational or college education are observationally the same as high school graduates regarding completion behaviour. This result is broadly consistent with Gunderson (2009), who noted that training tends to be more effective when it involves the upskilling of already skilled and educated workers. Mangan and Trendle (2008b) 
also find evidence for Australia that males who have completed high school are more likely to complete their apprenticeships than males who did not complete high school.

The number of years in the apprenticeship program provides an interesting - if not unexpected - correlate to each of the three states. As shown in Table 4, the probability of program completion monotonically increases until four years (the omitted category) and then decreases thereafter. Thus, there is an inverted "v-shaped" pattern in these data. A different pattern emerges for discontinuers as the probability generally decreases with duration in the program, before increasing again for durations greater than 10 years. For LTCs, the probability of remaining in the program increases with time (as expected). These results are not surprising, given that the normal length of most programs in these data is three to four years (Paquin 2009) and that the median length to completion has been estimated as four to five years (Morissette 2008).

\section{Provincial and trade group differences}

Table 4 presents results for the provinces, with the exception of Québec (Québec was excluded, as explained above). ${ }^{\mathrm{t}}$ Compared to Ontario (the omitted province), only Newfoundland and Labrador has a higher long-term continuation probability, with all other provinces being lower than Ontario. Conversely, Newfoundland and Labrador has a negative probability of completion compared to Ontario. Most other areas (with the exception of the territories) have completion probabilities significantly higher than that of Ontario. Discontinuation rates are highest in the territories.

The results for 24 trade groups derived from the 2001 National Occupational Classification are contained in the next panel of Table 4. The omitted category is carpenters and cabinet makers. Most of the other trades have completion probabilities which are higher than those for the omitted group (or, at least, no lower). The exception is heavy duty equipment operators, whose probability is 18.3 percentage points lower. Conversely, all other trades (again with the exception of heavy duty equipment operators) have discontinuation and LTC probabilities as low as, or lower than, those for carpentry and cabinet making. Several trades have very high relative completion probabilities, including hairstylist-esthetician, a category which is heavily skewed toward female participation. ${ }^{\mathrm{u}}$

\section{Friends and family in the trade}

From the extensive literature on college and university attendance, it is well known that parental education is positively associated with the educational outcomes of children. Unfortunately, the NAS does not include details on parental education, but it does contain variables on whether one's parents, close relatives, friends, and/or coworkers were involved in the individual's trade. Specifically, the NAS asks the question: "Did any of the following people ever work in that trade?" The possible answers to that question were the following: "Parents (father, mother)"; "Other close relatives (brother, sister, spouse, aunt, uncle, etc.)"; "Friends"; "Co-workers before apprenticeship"; and "None of the above." Respondents answered yes or no to these five separate questions. The results in Table 4 show no obvious pattern; the marginal probabilities are all fairly small in magnitude compared to many of the other variables included in the model. Ménard et al. (2008) report that contact with people exposed to the trade was the most common factor which influenced apprentices' interest in that trade. While these contacts may facilitate entry into an apprenticeship, they appear to be of little influence on completion. 


\section{Other background influences}

Table 4 also addresses various employment and other background factors which could influence the completion probability of apprentices. The unemployment rate ${ }^{\mathrm{v}}$ has only a small impact on the probability of long-term continuation. These results suggest that a 2-percentage-point increase in this regional rate would reduce the probability of long-term continuation by about 5 percentage points. The marginal effect of the unemployment rate on completion is positive and of the same magnitude, but is significant only at the $10 \%$ level (see Model 2). Although most research shows that registration in apprenticeships tends to be procyclical (see above), there appears to be little evidence of an unemployment-rate effect. Thus, program entry may indeed be procyclical, but these results suggest that completion is neither procyclical nor countercyclical. ${ }^{\mathrm{w}}$

All provinces offer a YAP where young people can work in the trades (and perhaps towards certification) while completing their high school diplomas. High school students may not be registered in a YAP but may nevertheless be exposed to various trades by taking trade and vocational courses or by taking part in co-op or high school work experience programs. A dummy variable was coded to one when individuals took part in a YAP, and another dummy was included for participation in any of these other programs. Given early exposure to trades via these channels may ultimately have an impact on program completion. Being involved in a YAP during high school has the counterintuitive effect of decreasing the probability of completion and increasing the chance of long-term continuation. ${ }^{\mathrm{x}}$ The results in this table show that taking part in trade-related or co-op programs during high school has no relationship to program completion behaviour in this model. These results are also supportive of the qualitative evidence of Taylor and Watt-Malcolm (2007).

A variety of job-related characteristics are also included in Table 4. The NAS asks if the individual had difficulty finding an employer willing to take on apprentices when he or she started the program, if he or she is a union member at this time, and if there was a journeyperson present at all times during the apprenticeship. Many of the results here are small and not statistically significant. Having a journeyperson always present during training does have a small positive influence on completion. Speaking a different language at home and at the (most current) job reduces the probability of completion by some 4.5 percentage points, although due to the construction of this variable, too much confidence should not be placed in this estimate. ${ }^{y}$

\section{Technical training, number of employers, and firm size}

Since technical training is an integral part of most apprenticeship programs, accessing this training should increase the probability of completion. Indeed, preliminary work using these data showed that accessing any type of technical training greatly increased the probability of completion. Table 4 further investigates this preliminary result by addressing the specific types of training undertaken. The other category includes those few individuals who took multiple types of technical training as well as individuals who took types of technical training not elsewhere categorized. Taking no technical training is the reference group. Those who took only long-block training (three weeks or more per year) show higher probabilities of completion. Although those with day training (one or two days per week) and self-paced training (including alternative forms of training such as distance education) also have higher completion probabilities. 
The number of employers that an apprentice had during the time of the apprenticeship is also addressed. A larger number of employers might signal, for example, difficulties with finding steady employment, obtaining technical training, working with journeypersons, or a lack of commitment to the trade. It may also indicate that the apprentice was seeking an employer who was a better match with his or her skills. Increasing the number of employers beyond one increases the probability of long-term continuation but decreases the probability of completion. Mangan and Trendle (2008b) also find that males in Australia who have worked with a single employer have a higher probability of completion.

Finally, the size of the firm where the individual last received training may be an important correlate of completion behaviour. The results in Table 4 show that completion probabilities are enhanced for those working at medium-sized firms (i.e., between 20 and 500 employees), but decrease as firm increases, although the lack of statistical significance on the larger firm coefficients may be due to their relatively small numbers.

\section{Conclusions}

The 2007 NAS contains information on individuals who were registered as apprentices in the 2002-2004 period and were then surveyed about their experiences in 2007, including whether these individuals were long-term continuers, completers, or discontinuers at the time of the survey. Using a series of multinomial probit models, there is a great deal of consistency between these results and the existing Canadian literature, which generally uses qualitative data or simple cross tabulations. The results also tend to be robust to different model specifications.

It is found that several demographic and job-related variables are related to the three states contained in the NAS. Divorced and single individuals, Aboriginals, visible minorities, having an activity limitation, and low education levels are all negatively related to completion. Time in apprenticeship programs, type of technical training, trade group, and province of residence are also all important correlates of program continuation, completion, and discontinuation. Having a journeyperson present during training is statistically significant, but the coefficient is small in relation to other factors. There is also evidence that the regional unemployment rate is related-positively but only weakly-to program completion. This may be the result of apprentices being able to complete their technical training or having better access to trained journeypersons during an economic slowdown.

Further research might address the differences in completion probabilities by trade group and by province. Apprenticeship training in Canada is the domain of the provinces and the territories, and often program requirements for the same trade differ by jurisdiction. Researchers could exploit these differences to identify elements of program design positively associated with completion rates. Looking specifically at the "red seal" trades-those for which provincial and territorial credentials are accepted nationallymight be particularly useful in this regard. Similarly, research might focus on the benefits to program completion. While many trades are compulsory (i.e., one needs to be an apprentice or a journeyperson in order to work in the trade), others are not. This implies that there may be little or no benefit to completing training in some trades. An analysis of wages of completers versus non-completers might help explain some low completion rates in some trades. In a related matter, the probability of employment 
may not be enhanced by completion in certain trades thus reducing the incentive for attaining the status of journeyperson. Finally, a more detailed examination of the variety of obstacles encountered by apprentices during training may be useful in redesigning programs with the goal of increasing the number of completions.

\section{Endnotes}

${ }^{\mathrm{a}}$ For recent examples and discussion of this work see Finnie et al. $(2008,2010)$.

${ }^{\mathrm{b}}$ Full-time enrollments in undergraduate programs in Canada were 481,053 in 1995/ 96 and 654,403 in 2007/08 (CANSIM Table 477-013).

${ }^{\mathrm{c}}$ As of 31 October 2006, there were 428,805 full-time students enrolled in college programs leading to college certificates or diplomas, post-diploma programs, collaborative degree programs, university transfer programs, and college preliminary year courses. See CANSIM Table 477-0015.

${ }^{\mathrm{d}}$ Admittedly, this is a rather rough calculation of completion rates. In the PSE literature, it is common to use longitudinal data to calculate completion rates. These data allow researchers to track individuals over time and so actual program length can be calculated from program start and end dates. Then, a completion rate can be calculated by dividing the number of number of completers in a cohort by the number of entrants in that same cohort. Unfortunately, these data are not currently available. Given the increase in the number of entrants over this 12-year period (Table 1), coupled with the time it may take to complete a program, readers may wonder whether the completion rates as calculated in Table 2 underestimate the true completion rates. The likely answer is yes, although the growth in the number of completions is still only about one-third as large as the $120 \%$ increase in the total number of registrations (Table 1). The raw data used to calculate the rates in Table 2 show that the number of apprenticeship completions in 1995 was 17,075 , increasing to 24,495 in 2007-an increase of about $43.5 \%$.

eAuthors' calculations based on CANSIM Tables 477-0013 and 477-0014.

${ }^{\text {f }}$ See http://www.ellischart.ca (accessed 1 April 2010).

${ }^{g}$ Boothby and Drewes (2006) estimate the weekly earnings premium for 25-to-34-yearold males with trades (and a high school diploma) to be about 15 percentage points higher than those with only a high school diploma in 2000. For females, the comparable estimate is a statistically insignificant 4.5 percentage points. However, Boothby and Drewes are unable to compare those who completed trades with those who did not.

${ }^{\mathrm{h}}$ Multinomial logit models were used at first, but Hausman tests rejected the "independence of irrelevant alternatives" (IIA) assumption in a number of cases. Despite the higher computational costs of obtaining marginal effects from multinomial probit models compared to multinomial logit models, this study uses the former. In practice, however, the results from the multinomial logit models were similar to those presented below.

${ }^{i}$ A fourth choice is also theoretically possible: individuals can switch from one trade to another. Since the data are specific to the trade in which the apprentice is registered in the 2002-2004 period, switchers are not observed.

${ }^{j}$ Due to different apprenticeship programs in different provinces, the error terms of individuals within provinces could be correlated. As such clustering within provinces is controlled for in all estimates.

${ }^{\mathrm{k}}$ Other data were considered as well. The Youth in Transition Survey (YITS) is very rich in family background, school experience, and aptitude variables, but it is difficult 
to identify those in apprenticeship programs. The 2006 Census of Population did ask specific questions regarding apprenticeship training and completion, and has a large sample size for analysis. Unfortunately, it lacks the richness of background variables which have been shown to be important controls in the PSE literature addressing college and university choice. The Registered Apprenticeship Information System (RAIS) is useful for the fact that it contains administrative-not survey-data and therefore is likely to have fewer measurement errors. However, the data available through the RAIS have limited background variables.

${ }^{1}$ A limitation of these data is that they include only long-term continuers, defined as those who began their programs before 2000 and who had not completed their certification by the end of the survey period in 2004. Short-term continuers were not in the scope of the survey. Statistics Canada randomly selected the survey respondents from the administrative data lists provided by the provincial and territorial apprenticeship authorities. Some of these lists may not have been up-to-date; consequently, a number of short-term continuers were contacted and interviewed by Statistics Canada. These individuals are also included in the analysis. As with any survey data, there is the possibility that there exists non-random error in questionnaire responses. See Laporte and Mueller (2010) for a brief discussion of this issue with respect to the NAS data used here.

${ }^{\mathrm{m}}$ Including those who started their apprenticeship program at ages 14 and $15 \mathrm{did}$ not change the results.

${ }^{\mathrm{n}}$ Some $63 \%$ of those who discontinued a program as of 2004 had returned to an apprenticeship program by 2007 (Ménard et al. 2008). This result suggests that one-time dropout rates should not be taken to imply discontinuation in the long-term. These results are similar to those obtained by Finnie and Qiu (2008), who show a similar phenomenon occurring at universities and colleges.

${ }^{\circ}$ It should be noted that this variable is coded to one (zero otherwise) for individuals who speak a different language at home than at the worksite, where the worksite is the most recent job held. This may or may not reflect the language most often spoken at the worksite during the apprenticeship period. Given the number of apprentices who complete their programs with one employer, coupled with the high probability of remaining with the same employer following completion, this seems like a reasonable assumption to make.

${ }^{\mathrm{P}}$ As mentioned above, multinomial logit (MNL) models were initially used, since they are computationally more efficient, but Hausman tests rejected the "irrelevance of independent alternatives" (IIA) assumption in a number of cases. Despite this, the results from the MNL models were very similar to the results presented here. In addition, the models were also estimated using the apprenticeship status during the survey frame (2002-2004). Reasonably similar results to those presented here were found. Various other model specifications were attempted. They are not reported here in the interest of parsimony, but all are in accord with the results presented here.

${ }^{\mathrm{q}}$ In Model 1, the coefficient on male is significantly negative in the first specification but then becomes positive and significant at the $10 \%$ level in the second model when major trade group controls are added. A separate regression (not shown), which excluded the hairstylist-esthetician trade group, also yielded a positive coefficient on the male variables, again significant at $10 \%$.

${ }^{\mathrm{r}}$ In the NAS, North American Indian, Métis and Inuit are grouped together under the same question and as a result the term Aboriginal has been used in this paper. 
${ }^{5}$ Variables for having an immigrant mother and/or an immigrant father were also included as variables in the model. The rationale for this was that the NAS contains no information on parental educational background and that many immigrant groups (e.g., Eastern Europeans) are heavily involved in the trades. Given the heritability of education in general, this variable is included in order to pick up this effect. The results are generally small and/or statistically insignificant.

${ }^{\text {t}}$ To see whether there were differences between Québec and the rest of Canada, two separate multinomial probit models were estimated, one with Québec and the other without Québec, but limiting the sample to only those in construction trades (not reported here). This was done since the non-construction trade groups in Québec were either underreported or not reported in the NAS. The results between the two models were consistent with the main results presented here. An interesting difference was that the unemployment rate in both estimates was positively and statistically related to completion behaviour. Thus, the probability of completion could be positively influenced by the regional unemployment rate in the construction trades, whereas this cannot be said for the main estimates, which include all trades but exclude Québec (Table 4).

${ }^{\mathrm{u}}$ It is worthwhile to note that the inclusion of trade groups changes the coefficient on male completion from a highly significant -10.5 percentage points to a positive 5.1 percentage points, significant at the 10\% level. Compare Models 1 and 2.

${ }^{v}$ This is defined for every respondent as the annual unemployment rate in the last year of his or her apprenticeship program by economic region (according to each person's postal code).

${ }^{\mathrm{w}}$ When estimating these models using the apprenticeship status over the 2002-2004 frame, there was no significant relationship between any of the three states and the unemployment rate. Given the nature of the 2002-2004 data, the average unemployment rate from 2002-2004 was used, and not the unemployment rate at the time of program completion for discontinuers and completers as has been done here.

"Arguably, this could be the result of "streaming" into these programs amongst those who may not be academically gifted. To address this, the YAP variable was regressed on high school grades (not reported); no evidence of streaming was found. In fact the opposite was found, as participation in these programs increased in grades. It is quite possible, however, that high school grades are endogenous to the simple model if the grades as reported were tallied after the student moved into the YAP and improved his or her grades in the new program, thus biasing the results in the simple regression. There is no way of addressing this potential endogeneity in these data.

${ }^{y}$ Unfortunately, the NAS does not ask a question regarding the language most often spoken during the apprenticeship program; this language may be different (especially in the case of completers and discontinuers) from the language currently spoken on the job. See footnote o.

Competing interests

The authors declare that they have no competing interests.

Authors' contributions

$\mathrm{CL}$ and REM contributed equally to the conception of the paper, the modelling, the empirical work and the writing of the paper. 
also thank the Canadian Labour Market and Skills Researcher Network (CLSRN) and Human Resources and Skills Development Canada (HRSDC) for supporting this research, Grant Schellenberg, Pamela White and an anonymous referee for useful comments, and finally participants at the January 2010 HRSDC-CLSRN Apprenticeship Workshop in Vancouver and many colleagues at Statistics Canada and HRSDC for useful discussion.

\section{Author details}

${ }^{1}$ Statistics Canada, Analysis Branch, Social Analysis Division, Ottawa, ON K1A 0T6, Canada. ${ }^{2}$ Department of Economics, University of Lethbridge, Lethbridge, AB T1K 3M4, Canada.

Received: 12 June 2013 Accepted: 13 June 2013

Published: 16 July 2013

\section{References}

Akyeampong EB (1991) Apprentices: Graduate and drop-out labour market performances. Perspect Lab Income 3(1): . Statistics Canada Catalogue no. 75-001-X

Bilginsoy C (2003) The hazards of training: Attrition and retention in construction industry apprenticeship programs. Ind Labor Relat Rev 57(1):54-67

Boothby D, Drewes T (2006) Postsecondary education in Canada: Returns to university, college and trades education. Can Publ Pol 32(1):1-22

Brunello G (2009) The Effect of Economic Downturns on Apprenticeships and Initial Workplace Training: A Review of the Evidence. Empir Res Vocat Educ Train 1(2):145-171

Canadian Apprenticeship Forum (CAF) (2004) Accessing and Completing Apprenticeship Training in Canada: Perceptions of Barriers: A consultation report. Ottawa, Canadian Apprenticeship Forum

Canadian Apprenticeship Forum (CAF) (2009) "What's Happening in Apprenticeship Now: Stakeholders' Feedback on the Barriers to Apprenticeship." Mimeo (May

Canadian Apprenticeship Forum (CAF) (2010) "High School to Apprenticeship Transition: Identifying and Sharing Best Practices." Mimeo (May)

Côté JE, Allahar AL (2007) Ivory Tower Blues: A University System in Crisis. University of Toronto Press, Toronto

Ferrer AM, Riddell WC (2002) The role of credentials in the Canadian labour market. Can J Econ 35(4):879-905

Finnie R, Qiu HT (2008) The Patterns of Persistence in Post-Secondary Education in Canada: Evidence from the YITS-B Dataset. Toronto. Educational Policy Institute. Queen's University School of Policy Studies, MESA Project Research Paper

Finnie R, Mueller RE, Sweetman A, Usher A (ed) (2008) Who Goes? Who Stays? What Matters? Accessing and Persisting in Post-Secondary Education in Canada. McGill-Queen's University Press. Queen's School of Policy Studies Series, Kingston (Ont.)

Finnie R, Frenette M, Mueller RE, Sweetman A (ed) (2010) Pursuing Higher Education in Canada: Economic, Social, and Policy Dimensions. McGill-Queen's University Press. Queen's School of Policy Studies Series, Kingston (Ont.)

Gunderson M (2009) Review of Canadian and International Literature on Apprenticeships. Vancouver (B.C.). Canadian Labour Market and Skills Researcher Network (CLSRN) Working Paper No. 27

Hausman JA, Wise DA (1978) A conditional probit model for qualitative choice: Discrete decisions recognizing interdependence and heterogeneous preferences. Econometrica 46(2):403-426

Laporte C, Mueller RE (2010) The Persistence Behaviour of Registered Apprentices: Who Continues, Quits, or Completes Programs? Vancouver (B.C.). Canadian Labour Market and Skills Researcher Network (CLSRN) Working Paper No. 62

Laporte C, Mueller RE (2011a) The Completion Behaviour of Registered Apprentices: Who Continues, Who Quits, and Who Completes Programs? Statistics Canada Catalogue no. 11F0019M. Ottawa, Ontario. Analytical Studies Branch Research Paper Series. No. 333

Laporte C, Mueller RE (2011b) The Persistence Behaviour of Registered Apprentices: Who Continues, Quits, or Completes Programs? Can Apprent J 4: . online at http://www.caj-jca.ca

Lehmann W (2004) 'For some reason, I get a little scared': Structure, agency, and risk in school-work transitions. J Youth Stud 7(4):379-396

Mangan J, Trendle B (2008a) Variation in Apprenticeship Cancellation Across Regional Queensland. Department of Education, Training and the Arts. Queensland Government. Labour Market Research Unit Working Paper No. 58

Mangan J, Trendle B (2008b) Surviving apprenticeship training: A duration analysis of apprenticeship contracts in Australia. J Interdiscip Econ 19(4):379-398

McFadden D (1974) The measurement of urban travel demand. J Public Econ 3(4):303-328

Ménard M, Menezes F, Chan CKY, Walker M (2008) National Apprenticeship Survey: Canada Overview Report 2007. Statistics Canada Catalogue no. 81-598-X. Minister of Industry, Ottawa

Morissette D (2008) Registered Apprentices: The Cohort of 1993, a Decade Later, Comparisons with the 1992 Cohort. Statistics Canada Catalogue no. 81-595-M. Ottawa

Mühlemann S, Wolter SC, Wüest A (2009) Apprenticeship Training and the Business Cycle. Empir Res Vocat Educ Train 1 (2):173-186

Paquin N (2009) Mobility of apprenticeship completers in Canada from 2002 to 2007. Education Matters 6(2): . Statistics Canada Catalogue no. 81-004-X

Raykov M, Livingstone DW (2005) Canadian Apprenticeship and Effect of Union Membership Status: Trend Analysis 1991-2002. The Future of Lifelong Learning and Work International Conference. University of Toronto, Ontario Institute for Studies in Education (OISE), Toronto. June 20-22 
Sharpe A, Gibson J (2005) The Apprenticeship System in Canada: Trends and Issues. Ottawa. HRSDC/Industry Canada/ SSHRC, Skills Research Initiative Working Paper B-06; and Ottawa. Centre for the Study of Living Standards Research Report No. 2005-04

Skof K (2006) Trends in registered apprenticeship training in Canada. Education Matters 3(2): . Statistics Canada Catalogue no. 81-004-X

Statistics Canada (2008) Microdata User Guide: National Apprenticeship Survey 2007. Ottawa

Sweet R, Lin Z (1999) Union Membership and Apprenticeship Completion. York University. Training Matters Working Paper Series.

Taylor A, Watt-Malcolm B (2007) Expansive learning through high school apprenticeship: Opportunities and limits. J Educ Work 20(1):27-44

Trendle B (2007) Cancellation of Indigenous Persons from the Apprenticeship Training Contract. Labour Market Research Unit. Department of Education, Training and the Arts. Queensland Government. Working Paper No. 47

doi:10.1186/1877-6345-5-1

Cite this article as: Laporte and Mueller: The completion behaviour of registered apprentices in Canada: who continues, who quits, and who completes programs? Empirical Research in Vocational Education and Training 2013 $5: 1$

Submit your manuscript to a SpringerOpen ${ }^{\circ}$ journal and benefit from:

- Convenient online submission

- Rigorous peer review

- Immediate publication on acceptance

- Open access: articles freely available online

- High visibility within the field

Retaining the copyright to your article

Submit your next manuscript at $\gg$ springeropen.com 